INTER NATIONAL MONETARY FUND
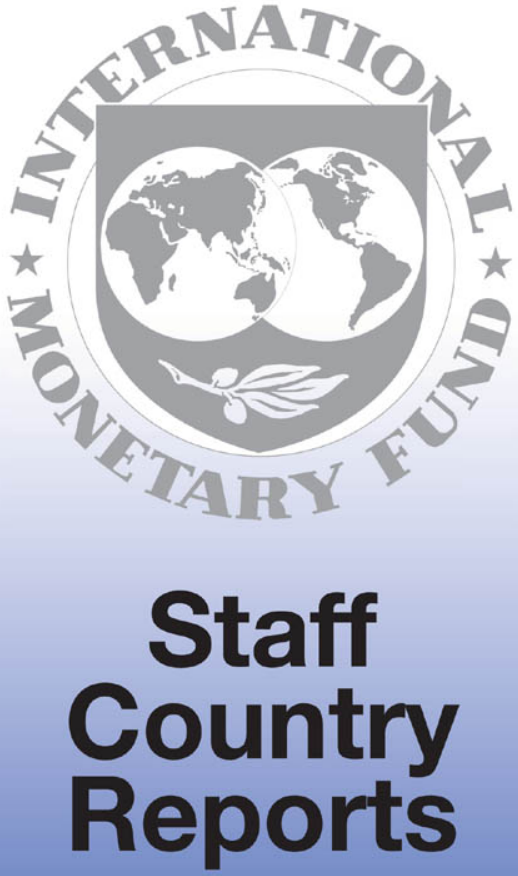
February 2000

IMF Staff Country Report No. 00/16

\section{Dominica: Staff Report for the 1999 Article IV Consultation}

This report was prepared by a staff team of the International Monetary Fund following discussions with the officials of Dominica on economic developments and policies. The report was then considered by the IMF's Executive Board in the context of the IMF's periodic consultation with Dominica, as required under Article IV of the IMF Articles of Agreement. The views expressed in the staff report itself are those of the staff team and do not necessarily reflect the views of the Executive Board of the IMF or of the authorities of Dominica; a supplementary statement by IMF staff may also be included. The views of the Executive Board as expressed in the discussion of the Article IV consultation report and as summarized in a Public Information Notice (PIN) are also included. In addition, a statement by the member country authorities may be appended. Further background documentation prepared by IMF staff for the consultation may be published separately at a later date. The policy of publication of Article IV staff reports allows for the deletion of market sensitive information.

This Article IV staff report is published-both in hard copy and on the IMF's website (http://www.imf.org)-as part of a pilot project. To assist the IMF in evaluating the pilot project for release of Article IV staff reports, reader comments on the staff report are invited prior to October 5, 2000, and may be sent by e-mail to Pilotproject@imf.org.

Copies of this report are available to the public from

International Monetary Fund - Publication Services

700 19th Street, N.W. - Washington, D.C. 20431

Telephone: (202) 623-7430 - Telefax: (202) 623-7201

Telex (RCA): 248331 IMF UR

E-mail: publications@imf.org

Internet: http://www.imf.org

Price: $\$ 15.00$ a copy

\section{International Monetary Fund \\ Washington, D.C.}


INTERNATIONAL MONETARY FUND

DOMLNICA

\section{Stall Report for the 1999 Article IV Consultation}

Prepared by the Staff Representatives for the

1999 Consultation with Dominica

Approved by Claudio M. Loser and Carlos Muñiz

December 14, 1999

Contents

Executive Summary...

I. Introduction 4

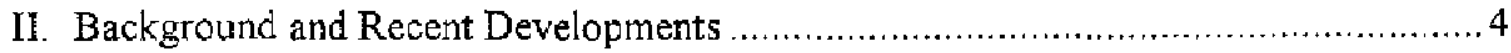

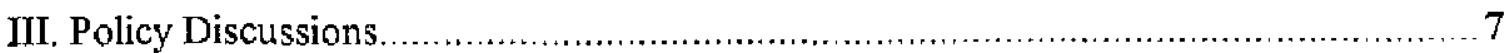

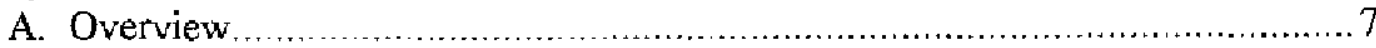

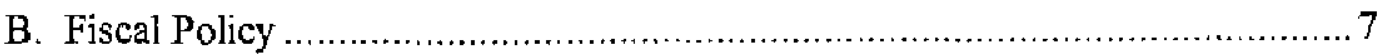

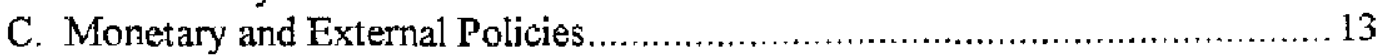

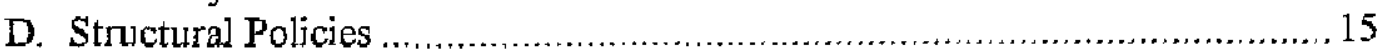

E. Poverty Alleviation and Environmental Protection.................................16

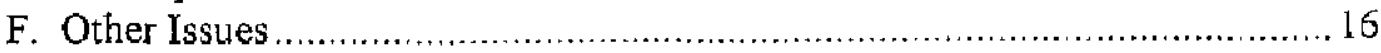

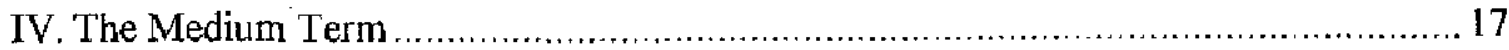

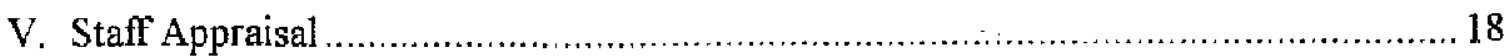

Tables

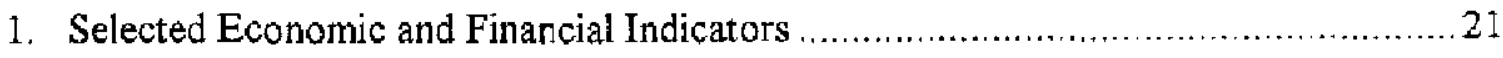

2. Consolidated Accounts of the Public Sector ..................................................22

3. Public and Publicly Guaranteed External Debt............................................... 23

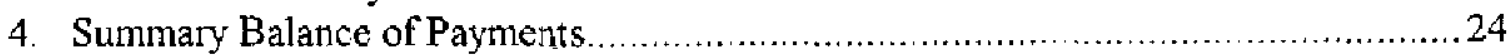

5. Summary Accounts of the Banking System …............................................ 25

6. Medium-Term Scenarios ........................................................................26

7. Cost and Funding Scenarios for Key Government Projects .................................27

8. Medium-Term Public and Publicly Guaranteed External Debt.............................28

9. Medium-Term Balance of Payments ..............................................................29 
Boxes

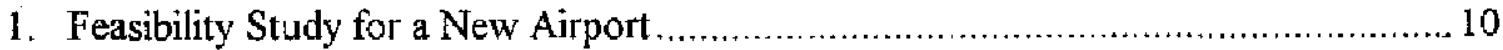

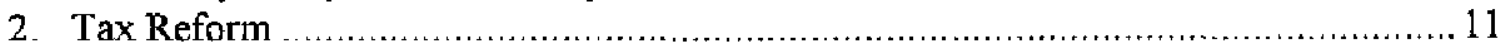

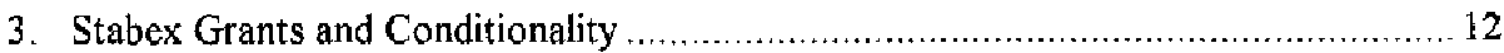

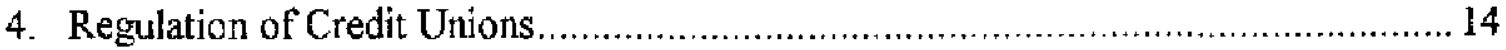

Figures

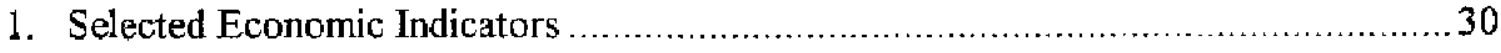

2. Selected Small Countries: Taxes, Central Government Wage Bill and Population .....31

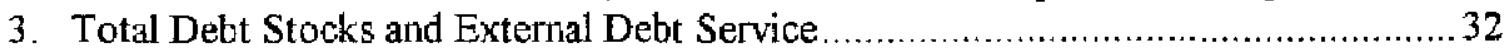

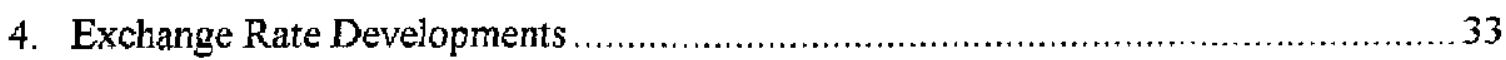

Appendices

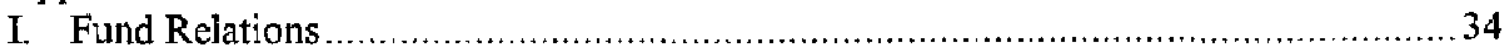

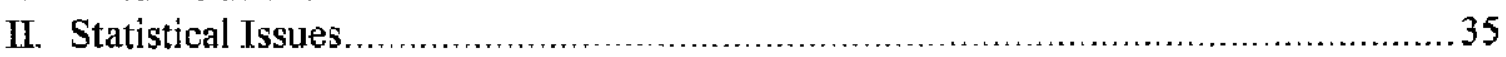

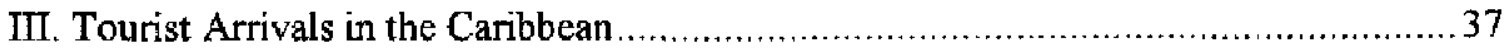

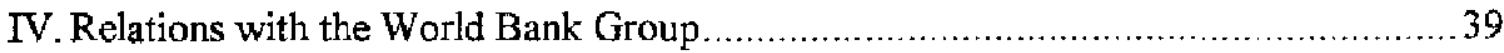

V. Financial Relations with the Caribbean Development Bank $\ldots \ldots \ldots \ldots \ldots \ldots \ldots \ldots \ldots \ldots 41$ 


\section{Background}

\section{Executive Summary}

- The structure of the economy has continued to move away from agriculture as the sharp contraction of the key banana sector has persisted, with real GDP growth averaging about $2 \frac{1}{2}$ percent in the 1990s. However, the growth of output was insufficient to reduce unemployment, which is believed to remain high. The resilience of economic activity in part reflects an expansion of utility services and the small manufacturing base, with the contribution of agriculture to GDP declining from 30 percent in the nid-1980s to 20 percent in 1998 . Meanwhile, further tourism development faces the challenges of regional competition and inadequate infrastructure.

- Despite a contraction in agriculture and construction, real GDP grew by $31 / 2$ percent in 1998 , largely as a result of a recovery in manufacturing production along with the continued expansion of services. Inflation remains low.

- The fiscal deficit remained broadly unchanged at $2 \frac{1 / 2}{2}$ percent of GDP in $1998 / 99$, but is projected to widen substantially in 1999/2000 because of the planned implementation of a large public sector investment program. To facilitate tourism growth and improve sports and recreation facilities in the country, the authorities plan to start construction of an airport and a stadium during the current fiscal year.

\section{Policy discussions}

- Even with the external assistance already pledged, building the airport and the stadium will require heavy borrowing in the near term, which would substantially increase debt service obligations in the period ahead, particularly if obtained on commercial terms. The authorities have already arranged the placement of US\$70 million in bonds with two foreign banks, about half of which was disbursed in November 1999.

- The mission advised the authorities to downsize their investment program and seek funding on better terms. It recommended foregoing the stadium and seeking the assistance of multilateral banks to find a more economical solution to the nead to improve air access to the country. The authorities acknowledged that their plans are very ambitious, carry risks, and have potentially serious implications for the public finances, but they are determined to press ahead with a strategy of giving a big push to tourism in the face of the continuing decline of, and bleak outlook for, the banana sector. They hope the economy would eventually grow out of the increased debt burden.

- The authorities were noncommittal about the mission's recommendation to sell the controlling stake in the National Commercial Bank and remaining shares in the telephone company to help fund the investment program, but indicated that they would seek private sector participation in the airport project. They agreed on the need to maintain vigilance over the financial sector, including offshore activities. 


\section{INTRODUCTION}

1. The 1999 Article IV consultation discussions with Dominica were held in Roseau during September 9-23, and at headquarters on September 26. The minister of finance and other senior government officials participated in the discussions. The mission comprised Messrs. Rosales (Head), Loevinger, Mathai, Pearson, and Go (Assistant) (all WHD). Ms. Williams from the Eastern Caribbean Central Bank (ECCB) and Ms. Dawson from the Caribbean Development Bank (CDB) accompanied the mission. Messrs. van Beek and Yadav (both WHD), Mr. Bernes, Executive Director for Dominica, Ms. Turner-Huggins, Advisor-to the Executive Director for Dominica, and Mr. Samuel, Senior Director of the ECCB, participated in the final meeting. Dominica is a member of the Eastern Caribbean Currency Union (ECCU), which has a common central bank (ECCB) and currency (Eastern Caribbean dollar).

2. Dominica accepted the obligations of Article VIII, Sections 2, 3, and 4 in December 1978, and it maintains no restrictions on payments and transfers for current international transactions. There was no credit outstanding to the Fund at end--November 1999 (relations with the Fund are presented in Appendix I). Dominica has not accepted the Fourth Amendment to the Articles of Agreement but has consented to the increase in its quota under the Eleventh General Review of Quotas.

3. Doninica is on the standard 12-month consultation cycle. At the conclusion of the last Article IV consultation on August 25, 1998 (SM/98/201), Directors emphasized the need to diversify the economy, improve infrastructure, raise public saving, strengthen the external position, and move forward with structural reforms, particularly in the areas of price decontrol, privatization, civil service reform, and trade liberalization.

4. Dominica provides the core minimum data to the Fund. However, shortcomings in the quality, timeliness, and coverage of the data hamper adequate monitoring of economic developments. For instance, data on imports for 1998 are only available through May of that year, with this deficiency mirrored in a lack of official estimates of aggregate demand. Also, the government lacks the capacity to produce quarterly estimates for GDP, the public finances, and the external accounts, and to compile the components of aggregate demand in real terms (Appendix II).

\section{BACKGROUND AND RECENT DEVELOPMENTS}

5. The structure of the economy has continued to move away from agriculture as the contraction of the key banana sector has persisted (Table 1), with real GDP growth averaging about $2 \frac{1}{2}$ percent in the $1990 \mathrm{~s}$. The growth of output, however, was insufficient 
to reduce unemployment, which is believed to remain high. ${ }^{1}$ The resilience of economic activity in part reflects an expansion of utility services and the small manufacturing base, with the contribution of agriculture to GDP declining from 30 percent in the mid-1980s to 20 percent in 1998. As in other countries in the region, the factors behind the contraction of the banana sector have inctuded plant disease, export price declines, and strong export dependence on uncertain preferential access to the European Union (EU) market. ${ }^{2}$ At the same time, further tourism development faces the challenges of regional competition ${ }^{3}$ and inadequate infrastructure.

6. Economic activity strengthened in 1998, while inflation remained low (Figure 1). Despite a contraction in agriculture and construction, real GDP grew by $3 \frac{1}{2}$ percent, largely as a result of a recovery in manufacturing production along with the continued expansion of services. The 12-month increase in consumer prices was 0.6 percent in September 1999, reflecting subdued import prices and the restrained credit policy of the ECCB, which has maintained the peg of the Eastern Caribbean dollar at EC \$2.70 per U.S. dollar since July 1976.

7. The public sector deficit remained broadly unchanged at $2^{1 / 2}$ percent of GDP in 1998/99 (fiscal year starts July 1), but public saving declined (Table 2). The central government deficit fell in relation to GDP due mainly to higher grant receipts, with government saving virtually unchanged. The surplus of the rest of the public sector declined, in part because arrears by the central government and private employers adversely affected the revenue of the social security agency (DSS). The stock of government arrears to the DSS rose slightly from end-June 1998 to end-June 1999, to about 3.2 percent of GDP. In August 1999, however, the govertment settled part of these arrears, with the stock declining to $2 \frac{1}{2}$ percent of GDP. The overall deficit of the Dominica Banana Marketing Corporation (DBMC) rose slightly as higher export prices did not make up for a decline in export volume, associated in part with the continuing exit of farmers from the sector (Table 1).

8. The gross debt of the nonfinancial public sector rose slightly, to 59 percent of GDP at end-June 1999, with central government gross debt rising to just over

${ }^{1}$ The last labor force survey pointed to an unemployment rate of about 23 percent in December 1997. This estimate is, however, unofficial, and the authorities harbor doubts about its reliability, in light of reported labor scarcities in the farming sector.

${ }^{2}$ A description of developments in the banana sector since the early 1990 s may be found in The Eastern Caribbean Currency Union-Recent Developments and Policy Issues (SM/99/69); the case of St. Vincent and the Grenadines is discussed in SM/99/265.

${ }^{3}$ Appendix III shows tourist arrival trends and the evolution of Dominica's market share in the region. 
51 percent of GDP. The stock of external arrears ${ }^{4}$ was virtually eliminated (Table 3), and external debt-service obligations declined to 5 percent of exports of goods and nonfactor services, the lowest level in recent years. The ratio of central government external debt service to central government revenue (excluding grants) is estimated to have declined to 5 percent at end-June 1999.

9. The external current account deficit is estimated to have narrowed to 7 percent of GDP in 1998 (Table 4). Although banana exports and tourism earnings fell, there was a strong recovery in soap exports and exports by a new toothpaste plant. Visitor arrivals grew by 4 percent in 1998 , but the share of arrivals staying in hotels declined. Net current and capital transfers from emigrants, workers abroad and foreign donors remained substantial in 1998 (9.3 percent of GDP), helping to cover the large trade deficit, with capital transfers to the government amounting to almost half the total. Net capital inflows have been sufficient in recent years to cover the current account deficits and permit surpluses in the overall balance of payments (as reflected in the changes in Dominica's imputed international reserves in the ECCB)

10. Broad money has continued to grow at a slightly higher rate than nominal GDP (Table 5). At the same time, commercial banks expanded credit to the private sector at a fast pace during 1998 and 1999, while maintaining a net external creditor position. Interest rates have declined somewhat since end-1997, with lending rates averaging around 11.3 percent per annum and deposit rates 4.1 percent per annum. Wide interest rate spreads have persisted, probably because of diseconomies of scale $^{5}$ and the relatively high proportion of nonperforming loans. The ratio of nonperforming to total bank loans fell from 16 percent at end-June 1998 to 15 percent at end-June 1999. Meanwhile, the ratio of provisions to nonperforming loans increased from 27 percent to 40 percent.

11. Some progress has recently been made in trade liberalization. Maximum tariff rates were reduced from 30 percent to 25 percent in January 1999, in line with Phase III of the scheduled reductions in the CARICOM common external tariff (CET). At that time, most

\footnotetext{
${ }^{4}$ The arrears have reflected past cash-flow difficulties of the central government, and are owed on contributions to international and regional institutions ( 0.8 percent of GDP) and to a lesser extent ( 0.1 percent of GDP) on debt service to these institutions and to bilateral creditors.

Since these arrears are owed entirely by the government, they do not evidence the existence of any exchange restrictions subject to the Fund's approval under Article VIII, Sections 2, 3, and 4 of the Fund's Articles of Agreement.

${ }^{5}$ See Ruby Randall, Interest Rate Spreads in the Eastern Caribbean, IMF Working Paper (WP/98/59, April 1998).
}

${ }^{6}$ Under Phase III of the CARICOM trade liberalization plan, several countries in the region had lowered the maximum CET to 25 percent in 1997. Phase IV calls for a further reduction 
remaining quantitative restrictions (on paints, plastic shoes, and fruits and vegetables) were replaced with tariffs that are to be reduced gradually over the medium term. Dominica is a member of the World Trade Organization (WTO) and maintains a liberal trade regime, with import-licensing limited to a small number of items mainly for health and security reasons.

\section{Policy Discussions}

\section{A. Overview}

12. While inflation remains low and growth has picked up, unemployment continues to be high and Dominica faces a difficult medium-term outlook. Notwithstanding regional efforts to help resolve the banana trade dispute, preferential access to the EU market for banana exports remains uncertain, as the WTO maintains that the European Union's modified system of trade preferences for ACP bananas contravenes world trade rules. ${ }^{7}$ To facilitate tourism growth and improve sports and recreation facilities in the country, the authorities are determined to start construction of an airport and a stadium during the current fiscal year.

13. The mission underlined the medium-term risk that-despite a likely acceleration of economic growth - the relatively high cost of the investment program would weaken the public finances and make the management of public debt difficult. It advised the authorities to downsize their investment program with assistance from multilateral banks, and to raise public saving and sell public assets to help fund it. The authorities acknowledged the need to secure multilateral assistance and raise public saving, noting that the latter is particularly challenging because of the relatively high tax burden and wage bill, which were about 24 percent of GDP and 15 percent of GDP in $1998 / 99$ (Figure 2).

\section{B. Fiscal Policy}

\section{Discussions centered on the economic and financial implications of the large-} scale investments planned for the period through 2003. These include the building of an international airport and supporting infrastructure as well as a stadium at a combined cost of US\$131 million (neatly 50 percent of estimated GDP for 1999). Taiwan Province of China has made a commitment to provide US $\$ 10$ million in grants and another US\$10 million in concessional loans (at an interest rate of 3.5 percent) to help finance the cost of the airport (US\$111 million). In addition, the authorities hope to obtain US\$14 million in grants from the

to 20 percent. See SM/99/69 (Table 27) for an overview of the implementation of the CET by the CARICOM member countries through early 1999.

${ }^{7}$ Dominica is actively participating in negotiations involving Ecuador, the United States, and the EU. 
EU for this purpose. Also, they have decided to earmark another US\$20 million grant from Taiwan Province of China ${ }^{8}$ exclusively to cover the entire cost of the stadium.

15. Even with the substantial grants just mentioned, the airport and the stadium projects will require borrowing of nearly US\$100 million in the near term, which would substantially increase debt service obligations in the period ahead, particularly if obtained on commercial terms. The authorities have already arranged the placement of US $\$ 70$ million in bonds with two foreign banks, about half of which was disbursed in November $1999 .^{\circ}$ On the basis of partial information provided by the authorities, the mission prepared medium-term scenarjos with (modified baseline) and without (baseline) these projects, to estimate the differential effects on the public finances over the ten-year period through FY 2008/09 (Table 6 and Figure 3). Under the modified baseline scenario, real GDP would grow at an average annual rate of $4 \frac{1}{2}$ percent, or some 1 percent faster than in the baseline. Preliminary estimates suggest that following the completion of the projects, the gross public debt would be higher than in the baseline by nearly 30 percentage points of GDP and the annual public interest obligations by 2.7 percentage points of GDP; public saving would turn negative.

16. The mission recommended that the public sector investment program be scaled down in order to avoid a large and abrupt rise in public debt. To this end, it advised the authorities to forego the stadium project, redirect the US $\$ 20$ million grant earmarked for this purpose to help fund the construction of a smaller airport, and adopt measures to increase public saving. Also, the mission encouraged the authorities to press ahead with privatization and engage the multilateral development banks in order to seek funding on better terms and secure specialized technical support. Both the World Bank and the CDB have expressed reservations about the airport project, but remain open to further discussions with the authorities (the World Bank is planning to send a mission to Dominica in December 1999).

17. The authorities acknowledge that their plans are very ambitious, carry risks, and have potentially serious implications for the public finances, but they are determined to press ahead with a strategy of giving a big push to tourism in the face of the continuing decline of, and bleak outlook for, the banana sector. They hope the economy would eventually grow out of the increased debt burden. In their view, a new airport will permit

${ }^{8}$ To be disbursed over ten years, in annual tranches of US\$2 million.

${ }^{9}$ The bonds are being purchased by the Royal Merchant Bank and Citibank Trinidad, both domiciled in Trinidad and Tobago. The bonds carry an interest rate of 9 percent, with maturities of 15 and 25 years. These banks, in turn, have issued mirror bonds to be sold in Dominica and elsewhere. The DSS and the state-owned National Commercial Bank (NCB) have bought mirror bonds for US\$5.4 million and US\$2.8 million. At the same time, the government used part of the funds obtained from the banks to reduce its arrears with the DSS. 
diversification of tourism by adding all-inclusive resorts to the present ecotourism sites, and they do not see the lack of suitable beaches as an insurmountable obstacle to resort operations. The airport feasibility study (Box 1) will be made available to the public, and other project details will be posted on the Internet to ensure wide dissemination and transparency.

\section{The execution of the large investment program envisaged by the authorities} would likely magnify the problem of low public saving and could imperil the ability of the government to meet its financial obligations. The mission underlined the new urgency of fiscal action to prevent such severe deterioration of the public finances. An adjustment program should focus on restraining current expenditure, in particular the wage bill, outlays on goods and services, and transfers. Thus, there would be a need to freeze the size of the civil service and maintain a policy of wage moderation. To address staffing constraints in key government areas, the mission suggested identifying staffing redundancies and redeploying staff to higher priority functions (including tax administration). Also, it stressed that the government should regularize its financial relations with the DSS, and clear remaining arrears. ${ }^{10}$ At the same time, the mission urged early action to reform indirect and property taxation, in line with FAD recommendations (Box 2), " as well as to strengthen tax administration by allocating sufficient resources to the revenue department and providing it with support in the strict enforcement of the tax code and the timely application of penalties.

19. The authorities recognize that raising public saving should be a priority, including because of the conditionality set for continued EU assistance (Box 3), but see no scope for immediate strong action. In the meantime, they hope to secure increased external assistance and find ways to bring private participation into the operation and funding of the airport. They believe that the low level of government saving is a structural problem related to the narrow revenue base and high unit costs of administration in the small countries of the region. Nevertheless, they are looking forward to eventually establishing a timetable for the introduction of a VAT following ongoing consultations with various social sectors. They agree that replacing a number of indirect taxes with a VAT and streamlining exemptions would help broaden the tax base and improve efficiency and buoyancy. They also recognize the need to strengthen tax administration.

\footnotetext{
${ }^{10}$ External payment arrears amounted to US\$2.3 million at end-June 1999 , including US\$2.1 million of arrears in contributions to international and regional institutions.
}

${ }^{11}$ At the request of the authorities, a mission from FAD provided assistance in March 1999 on the design of a tax reform aimed at replacing a number of indirect taxes with a VAT. Two previous FAD missions (1995 and 1997) had advised on tax reform and budgetary practices. 


\section{Box 1. Dominica: Feasibility Study for a New Airport}

Dominica currently has two airports-Canefield, a small facility close to the capital, and Melville Hall, a slightly larger facility located an hour's drive away. Neither airport has the capacity to operate at night or accommodate jet landings. The authorities believe this limits the growth potential of the tourism industry, 'which they view as the main pillar of economic diversification. They believe tourists and charter operators will continue to choose other destinations over Dominica because of the lack of jet service, direct service from Europe and the United States, and night landing capacity, which compels tourists from Europe and the Western United States to spend one to two days in transit. A feasibility study commissioned to private consultants developed three scenarios, based on assumptions about the growth of hotel rooms and tourist arrivals. The study concluded that Melville Hall will reach full capacity during 2004-06, It argued that airlines will only be willing to increase service if they can use jets, and called for an airport capable of handling 300-seat jets and a terminal capable of handing 300 passengers per hour.

Sumunaty of Scenarios

Average anthual grouth rate of hotel nooms (1998-2010)

Average annual growth rate of stayover visitors (1998-2010)

Number of hotel raoms in Dominica in 2010 (764 in 1997)

By 2010 , accommodation capacity in Dominjea would be similar to 1997 capacity of ...

Number of visitors in $2010(68,000$ in 1997)

By 2010 , number of aircraft landings would be similar to 1997 landings of ...

$\begin{array}{ccc}\text { Low } & \text { Middle } & \text { High } \\ & & \\ 10.8 & 12.4 & 16.3 \\ 9.4 & 10.8 & \mathbf{1 3 . 7} \\ 2884 & 3500 & 5500 \\ \text { Antigua and Barbuda, } & \text { St. Lueia, } & \text { St Martin, } \\ \text { Trinidad and Tobago } & \text { Belize } & \text { Earbados } \\ 220,000 & 260,000 & 363,000 \\ \text { Trinidad and Tobago } & \text { St. Ltscia } & \text { Barbados }\end{array}$

As recognized in the feasibility study, its tourism projections are highly optimistic. Even under the most pessimistic of the scenarios, the growth in hotel rooms and tourist arrivals in 1998-2010 would be unprecedented in the region. Given that growth in tourist arrivals 1998-99 was much less than had been projected, there is a chance that capacity at Melville Hall will be sufficient through 2010 .

The authorities are of the view that lower cost alternatives (lighting the existing runway and/or building a more modest runway) would not yield significant savings. While there is widespread agreement about the need to install night landing capacity, there appears to be little support in the business community for building a costly new airport with jet landing capabilities. Lower cost and smaller scale airport improvements may be better alternatives particularly as airlines are emphasizing hub and spoke operations and neighboring islands with large airports could serve as transit points for Dominica-bound tourists. There is some evidence that requiring passengers to change planes, may not have limited the growth of air travel in the United States and Europe. Also, the British Virgin Islands receives roughly 250,000 stayover arrivals per year with only turboprop service, which suggests that the lack of jet service might not be a major constraint to tourism in Dominica.

${ }^{1}$ Building all-inclusive resorts and attracting charters are part of the authorities' strategy to broaden the base of the tourism sector. 


\section{Box 2. Dominica: Tax Reform ${ }^{3}$}

Dominica's system of indirect taxation is complicated and distortionary. Most indirect tax revenue stems from a 25 percent consumption tax (which is largely collected at the import stage), a 3 percent retail sales tax, and a 5 percent hotel occupancy tax. In addition, there are import duties, customs charges, customs surcharges, stamp duties, and other levies, many apparently generating too little revenue to merit their administrative costs. Exporters receive no credit for taxes paid; tax cascading is common; and the fast-growing service sector is almost completely uncovered, adversely affecting revenue buoyancy. This is a matter of concern given Dominica's commitment to reduce external tariffs within CARICOM, which will likely lead to a decline in import duty collections. In response to these problems, the authorities have granted a plethora of ad-hoc tax concessions (exemptions and zero-rating), which further distort relative prices and harm the revenue base.

Recognizing these difficulties, the Minister of Finance, in his July 1998 budget address, raised the possibility of replacing a number of indirect taxes with a value-added tax (VAT). Technical assistance from the Fund was requested to this end, and in May 1999 a Fiscal Affairs mission recommended replacing the consumption, sales, hotel, and other minor taxes with a credit-method value-added tax, applicable at a single rate, that would include most services and be subject to very few exemptions. With such a broad base, distortionary effects would be minimized; buoyancy would be increased, and credits for taxes paid on inputs would redress tax cascading. The mission recommended zero-rating for exports, and supplementing the VAT with excise taxes on fuels and a few other goods. The mission estimated that a VAT rate of 18 percent would be consistent with revenue neutrality. It was felt that an 18-month period would be necessary to draft the legislation, conduct public information campaigns, and hire and train new auditors. The Inland Revenue Service (IRS) would likely need 20-25 additional employees to handle the demands of the VAT.

The FAD mission recommended that equity concerns be addressed with the following combination of policies: (1) an exemption for completely unprocessed agricultural foods; (2) direct cash transfers to the poor; (3) an exemption for healthcare and education; and (4) an exemption for small businesses (with annual turnover of less than EC\$60,000), as these firms are more likely to be patronized by poorer customers (and because such small firms would likely be ill-equipped to handle the paperwork requirements of a VAT).

${ }^{1}$ Based on "Dominica: Introducing a Value-Added Tax," Fiscal Afairs Department, IMF, May 1999. 


\section{Box 3. Deminica: Stabex Grants and Conditionality}

Since the early 1990s, the Europem Union (EU) has supported the banana industry in Dominica-m-as well as in the other Windward Islands and in other ACP nations-not only through preferential access to the EU market, but also with disect cash payments under the system of stabilization of export earnings from agricultural commodities (Stabex). The cumulative allocation of these Stabex transfers to Dominica for the five year period 1993-97 has amounted to ECU 37.2 million.

Stabex grants are intended, most narrowly, simply to compersate for losses in export earnings due to adverse climatic and market conditions. More broadly, they are also meant to help improve the local industry's competitiveness by funding investments in irrigation systems and other modernization measures.

The recent World Trade Organization (WTO) ruling against the EU regime calls into question the future of the banana industry in Dominica and other high-cost countries. White in 1988 there were 7,000 banana farmers in Dominica, one decade later, the number had dropped to less than 3,000 , and it seems likely that this trend will continue. In recognition of this reality, the share of Stabex funds channcled into the banana sector bas, over the past few years, steadily declined. Instead, funds are now allocated to a variety of programs aimed at promoting agricultural and economic diversification, easing farmers' transition out of the banana industry, and redressing the poverty and social displacement that could result from such major structural change. Stabex programs include farmer retraining, road rehabilitation, tourism development, and general education and health.'

The Stabex allocations for the years 1996 and 1997 (which are scheduled to be disbursed in three annual tranches over the period 1999-2001) are governed by a Framework of Mutual Obligations (FMO). This document specifies the total amount of money which the EU is committing as well as the manner in which funds are to be disbursed, the types of ventures that will be supported, and the conresponding ohligations of the Government of the Commonwealth of Dominica. As described by the FMO, Stabex funds can go either to the general funding of the Public Sector Investment Program (PSIP) or to fund specific projects. The following chart provides a breakdown of FSIP versus project funding, as well as the amounts (in Euros) allocated to different sectors:

\begin{tabular}{lrrr} 
& PSIP Support & Project Support & \multicolumn{1}{c}{ Total } \\
Technical assistance & 400,000 & & 400,000 \\
Diversification of the economy & $\mathbf{3 , 8 0 0 , 0 0 0}$ & & $3,800,000$ \\
Social and community development & $\mathbf{2 , 8 5 0 , 0 0 0}$ & 750,000 & $\mathbf{3 , 6 0 0 , 0 0 0}$ \\
Private sector development & & 250,000 & 250,000 \\
Agricultural diversification & 950,000 & & 950,000 \\
Monitoring, auditing and evaluation & & 374,346 & 374,346 \\
Total & $\mathbf{8 , 4 0 0 , 0 0 0}$ & $\mathbf{1 , 3 7 4 , 3 4 6}$ & $\mathbf{9 , 3 7 4 , 3 4 6}$
\end{tabular}

Disbursement of the project-related funds depends on favorable cost-benefit analyses of the projects in question. Also, the PSIP funds are conditional on maintaining certain economic policies (and on previously committed funds having been disbursed at least at a 70 percent rate). First is the requirement to preserve fiscal discipline: central government saving must be 1 percent of GDP in 1998/99, 1.6 percent of GDP in 1999/2000, and 1.8 percent of GDP in 2000/01; similarly, public sector saving is required to be 1.4 percent of GDP, 1.7 percent of GDP, and 2.1 percent of GDP in those years. This requirement is intended to ensure sufficient counterpart funds for Stabexrelated projects, and to allow Dorninica to comply with the second major requirement of the FMO: to keep current expenditures on health and education at least constant in real terms, and to maintain capital expenditures for these sectors at least at the levels programmed in the PSIP for 1998-2000. The third major requirement was met when Dominica implemented Phase JII of CARICOM's Common Extemal Tariff (CET) on January 1, 1999, with Phase IV to be carried out prior to the disbursement of the second tranche.

${ }^{1}$ The EU is also currently considering a ten-yeat "special system of assistance" to complement the system of Stabex grants 
20. On present trends and policies, the public sector deficit is projected to widen to 9 percent of GDP in 1999/2000. This would be the result mainly of the large increase in public investment associated with the start of the airport and stadium projects as well as with upgrades in the water and sewerage infrastructure carried out by the water company (DOWASCO). While the overall deficit of the central government would reach about 10 percent of GDP, the combined overall position of the rest of the nonfinancial public sector would remain in surplus. However, the weakness in the finances of the DBMC would persist notwithstanding ongoing efforts to restructure the banana industry, improve farmer efficiency, and run the industry on a strictly commercial basis. Public saving is projected to decline further and government saving to turn negative.

\section{Monetary and External Policies}

21. In the context of the currency union, the Dominica authorities exert little control over monetary and exchange rate policy. The credit policy of the ECCB is aimed at providing strong foreign exchange backing for currency issued, thereby supporting the fixed exchange rate. ${ }^{12}$ Economic growth and confidence in the currency have continued to contribute to the private sector's demand for credit and domestic financial assets in recent years. Since 1984, the ECCB has maintained a floor of 4 percent on interest rates on passbook savings deposits, which account for over half of bank deposits in Dominica. In the view of the authorities, the minimum deposit rate protects small depositors from oligopolistic bank practices.

22. The authorities agree on the need to maintain vigilance over the financial sector. The ECCB, which is responsible for banking supervision in the region, recently reinforced its bank inspection procedures and surveillance over nonperforming loans. ECCB representatives acknowledged that the share of nonperforming loans in the total loan portfolio remains high; however, they noted that provisioning appears adequate and that most commercial banks are branches of large, well-capitalized Canadian and British banks. ${ }^{13}$

23. There is scope to strengthen surveillance over the operations of the large credit union sector and the growing number of offshore institutions. The mission recommended that supervision of nonbank financial intermediaries be intensified by jmproving data reporting requirements and transferring supervisory responsibility over credit unions to the finance ministry. It supported efforts to establish stronger regulations for the credit union industry, including provisions to ensure adequate reserves ( $\mathrm{Box} 4$ ), noting that Dominica has approved the "Harmonized Cooperatives Societies Bill" which aims to harmonize the regulatory

\footnotetext{
12 The "strong dollar" policy of the ECCB is described in The Eastern Caribbean Central Bank-Institutional Arrangements and Issues in a Currency Union, SM/99/70.

${ }^{13}$ See SM/99/70 for a description of banking supervision in the ECCB member countries.
} 


\section{Box 4. Dominica: Regulation of Credit Unions}

Credit unions account for around one-quarter of the financial sector's loans and deposits. The largest, Roseau Credit Union, holds about two-thirds of credit unions' loans and deposits. Because credit unions are not required to maintain unremunerated reserves, their deposit rates are generally higher, and lending tates lower, than those of commercial banks.

The Ministry of Community Development and Women's Affairs bas supervisory responsibility over credit unions. It uses nonbinding guidelines developed by the Caribbean Confederation of Credit Unions to assess the financial condition of credit unions. In practice, however, credit unions set their own prudential norms on capital adequacy, provisioning, and lending to individuals. 'The Dominica Cooperative Credit Union League provides examiners to members for internal audits. At the same time, credil unions transmit quarterly data to the ECCB on their balance sheet, operating income and expenditure, employment and nomperforming loats.

Liquidity requirements and practices appear weak. Currently, credit unions must set aside 20 percent of each year's net earnings as reserves. However, rather than holding reserves in low risk, liquid assets, many credit unions relend them. To improve reserve management, the Credit Union League established a common fund and suggested that credit unions place 25 percent of their reserves in it. However, in addition to holding Dominica government securities and bank deposits, the League lent to and placed deposits in member credit unions.

To strengthen the legal and regulatory framework, the authorities are developing new regulations based on the Organization of Eastern Caribbean States Motel Cooperatives Act. Key provisions of the draft regulations include;

- Requiring that reserves equal at least 10 percent of liabilities be placed in a separate demand account in another financial institution: ${ }^{2}$

- Limiting loans to any individual to no mote than 10 percent of capital;

- Requiring that provisions increase with the time loans remain non-performing, and that loans be written off when they have been non-performing for two years;

- Limiting the time interest may accrue before a lom is declared non-performing;

- Prohibiting credit unions from counting as income any interest which has accrued but has not been paid for cestain periods;

- Requiring credit union employees and directors to recuse themselves from decisions on loans to firms with which they have a fiduciary relationship;

- Restricting loans to employees and directors, as well as to firms controlled by them;

- Granting the ministry authority to demand operational changes if necessary to protect depositors; and

- Requiring each credit union to hold liquid assets and establish lines of credit as necessary to maintain suflicient liquidity.

Apart from the early approval of the proposed regulations, it would be important to set minimum liquidity requirements, and penalties for non-compliance as recommended in the Confederation's guidelines.

\begin{tabular}{|c|c|c|c|c|c|}
\hline \multirow{2}{*}{$\begin{array}{l}\text { Consolidated Prudential Ratios } \\
\text { for Dominica Credit Unions }\end{array}$} & \multicolumn{4}{|c|}{ December } & \multirow{2}{*}{$\begin{array}{r}\text { March } \\
1999\end{array}$} \\
\hline & $\overline{1995}$ & 1996 & 1997 & 1998 & \\
\hline Capital/(Shares + deposits) $^{1 /}$ & -6.7 & 4.2 & 2.3 & 4.2 & 3.5 \\
\hline Nonperforming loans/Total loans & 11.4 & 10.0 & 11.8 & 10.7 & 12.6 \\
\hline Reserves/Nonperforming loans & 48.0 & 144.3 & 123.1 & 146.3 & 1303 \\
\hline Reserves/Assets & 4.4 & 10,8 & 10.3 & 11.4 & 12.0 \\
\hline Loan/(Shares + deposits) & 55.6 & 49.7 & 47.5 & 49.1 & 49.1 \\
\hline Credit union loans/Total domestic loans & 23.8 & 24.2 & 23.2 & 23.7 & 23.8 \\
\hline Credit union deposits/Total domestic deposits & 22.8 & 26.7 & 27.8 & 27.1 & 26.5 \\
\hline
\end{tabular}

Source; Eastern Caribbean Central Bank.

${ }^{\prime \prime}$ Capital $=($ Assets - Nonperforming loans $)-($ Liabilities - Reserves $)$.

${ }^{1}$ For example, the Roseau Credit Union limits loans to any individual to EC 240,000. At end-June 1999, the Roseau Credit Union had set aside provisions, which cover only about $7 / 2$ percent of its outstanding non-performing loans.

${ }^{2}$ Current holdings of short and medium-term government securities would still count as reserves. 
framework faced by credit unions and other cooperatives in the OECS member countries. Calling attention to the granting of tax incentives to a mutual fund company in which the state-owned National Commercial Bank (NCB) and the DSS have a controlling stake, the mission stressed the need for uniform tax treatment of potential entrants to the mutual fund industry.

\section{The external current account deficit is estimated to increase to about 12 percent} of GDP in 1999, reflecting strong growth in imports and stagnant banana exports. Capital inflows to finance public sector operations, direct investment, and net borrowing by commercial banks would help maintain a surplus in the overall balance of payments. The stock of public and publicly guaranteed external debt, which is still mostly on concessional terms, would increase substantially as a result of the borrowing associated with the airport project, but the scheduled debt-service ratio would remain low.

\section{The authorities are satisfied that the present exchange rate arrangement has} served the country well. Measured for Dominica, the Eastern Caribbean dollar appreciated in real effective terms by 4 percent from end-1990 to end-September 1999 (Figure 4). As the Eastern Caribbean dollar is pegged to the U.S. dollar, movements in its real effective exchange rate are related largely to changes in the value of the U.S. dollar vis-à-vis other major currencies. From the viewpoint of tourism activity, Dominica's regional competitiveness appears to have been broadly adequate, as Dominica's share in Caribbean tourism arrivals has remained largely unchanged (Appendix III), with net travel receipts growing at an annual rate of about 6 percent in recent years (Table 4 ).

26. Dominica, along with the other ECCB members, maintajns exchange controls on capital and nontrade current transactions. The indicative limit on foreign exchange purchases was increased in October 1997 to EC\$250,000 per person per year, from EC $\$ 100,000$. Purchases of amounts above this limit require approval from the ministry of finance, but all bona fide requests are routinely approved. ECCB representatives indicated that the gradual phasing out of the exchange controls is likely to continue in the period ahead.

\section{Structural Policies}

27. The priorities in the structural area are to downsize the civil service, advance trade liberalization, abolish remaining price controls, and reduce state participation in economic activity. The authorities do not envisage immediate progress in downsizing the civil service, but intend to further reduce the maximum tariff to the 20 percent target rate as soon as the CARICOM secretariat completes a study of the possible effects on industry and tax revenue. The authorities are trying to garner pubtic support for the removal of the price controls still in effect, which are not being enforced (except for those on cement and fuels), and have created a commission of private sector representatives that is to advise on their eventual elimination.

28. The mission argued for moving ahead with privatization and deregulation. In particular, it advised selling the government's controlling stake in the NCB and the remaining stake in the telecommunications company, which would help fund the airport project. The authorities are noncommittal about the sale of these assets. However, they are considering the 
elimination of the monopoly held by the state-owned Dominica Export-Import Agency (DEXIA) on the importation and distribution of bulk rice and sugar. They intend to transfer the trading of commodities other than bulk sugar and rice from DEXIA to a new entity, which subsequently could be privatized.

29. The mission stressed that success in diversification would depend on maintaining competitiveness and urged the authorities to exercise restraint on public sector wages in order to avoid sparking demands for higher wages in the private sector. It also drew attention to the reportedly high labor cost of moving cargo through the port and the crosssubsidization of residential users of water and electricity by commercial users. In the regulatory area, regional efforts continue with the aim of modifying the terms under which the foreign-owned telephone company operates, with a view to reducing the period granted to the company to maintain monopoly over the telecommunications business.

\section{E. Poverty Alleviation and Environmental Protection}

30. The authorities are persuaded that economic growth and education are essential for reducing poverty. Their objective is to extend universal education to the secondary level, where the shortage of classrooms is a key constraint. A program to expand and improve school infrastructure is being supported by the World Bank and the British government. Dominica has a modest safety net program that provides targeted assistance, including monthly stipends to the very poor.

31. Development of ecotourism requires efforts to conserve the environment. To this end, the PSIP includes projects to improve the water and sewage infrastructure and to protect the coastal areas. Cost recovery through fees continues to be regarded as important, including for waste management and ecotourism site maintenance.

\section{F. Other Issues}

32. There was broad agreement about the importance of addressing statistical deficiencies, $Y 2 K$ compliance, and the publication of the staff report. The mission encouraged the authorities to improve data compilation and dissemination, and to allocate sufficient resources to the statistical function. In particular, it highlighted the urgent need for quarterly public finance statistics (presently prepared on a fiscal year basis) and balance of payments data (presently prepared on a calendar year basis), to ensure consistency with the national accounts (presently prepared on a calendar year basis). As regards $\mathrm{Y} 2 \mathrm{~K}$ readiness, the government has appointed a national team to coordinate and oversee Dominica's effort at ensuring $\mathrm{Y} 2 \mathrm{~K}$ compliance. The authorities have agreed to participate in the pilot project for the publication of the staff report, but reserve the right to withdraw their decision once they have read the document. 


\section{THE MEDIUM TERM}

33. The authorities" medium-term objectives are set out in the "Medium-Term Economic Strategy Paper" that was presented to the Consultative Group for Cooperation in Economic Development in June $1998 .{ }^{14}$ These are to maintain low inflation and return the economy to a higher growth path based on a more diversified productive base. That document identifies pursuit of sound public finances as a principal policy to achieve these objectives.

\section{The staff has developed three illustrative medium-term scenarios (Table 6 and}

Figure 3). These represent the continuation of present trends and policies (baseline), the implementation of the authorities" ambitious investment program without the adoption of adjustment measures (modified baseline), and the implementation of a smaller investment program along with adjustment measures (alternative). A summary of the effects of the modified baseline scenario (relative to the baseline) was presented in paragraph 15 . The modified baseline and the alternative scenarios assume that hotel construction by foreign investors will sustain growth following completion of the airport and stadium projects. As noted, the public finances deteriorate substantially in the modified baseline scenario, as debt and debt service obligations rise sharply and public saving turns negative over the second half of the 10-year period of analysis. The high public borrowing requirement proves burdensome to the domestic banking system, with its net foreign assets declining sharply and its capacity to lend to the private sector greatly reduced.

35. A smaller scale investment program and fiscal adjustment would result in a more manageable macroeconomic situation over the medium-term. In the alternative scenario, grants presently earmarked for the stadium are used to fund a somewhat smaller airport project (Table 7). Also, it is assumed that multilateral loans for about US\$10 million permit an early amortization (2001/02) of some of the bonds already placed with Trinidad and Tobago banks. The proposed adjustment measures include freezing the size of the civil service, maintaining wage moderation, and restraining the growth of other noninterest current spending. The annual yield of these measures would be equivalent to 2 percent of GDP. It is further assumed that a revenue-neutral tax reform is introduced in $2002 / 03$, with a VAT replacing a number of indirect taxes, maximum external tariff rates reduced, and exemptions on income, import, and other taxes streamlined. Also, privatization proceeds of about US $\$ 10$ million are assumed to be derived from the sale of shares in the NCB and the telecommunications company in 2001/02.

${ }^{14}$ This paper is currently being updated. 
36. With the proposed adjustment measures, the public sector would be able to meet the debt service obligations incurred to build the smaller airport and reduce its debt in relation to GDP at a swift pace, aided by the strong growth in economic activity (Table 8). The preservation of a manageable fiscal situation would help maintain private sector confidence and the capital inflows that finance the external current account deficit. Following a rise during the airport construction period, this deficit would decline, to 9 percent of GDP in 2004, and would be financed largely by capital transfers and direct investment (Table 9). The external current account would remain sensitive to shocks affecting tourism and/or banana exports. For example, if beginning in 2000 , banana export earnings were to decline to half the 1998 level; the external current account deficit would average about 14.5 percent of GDP over 2000-09.

\section{STAFF APpraisal}

37. The authorities' main policy objective is to create the basis for the sustained growth of output and employment through economic diversification and financial stability. They agree that achievement of these objectives requires raising public saving to support improvements in infrastructure and promoting private activity through structural reforms. While they will consider raising public saving over the medium term, they are not prepared to make any immediate major policy change. They hope to secure increased external assistance, but are prepared to borrow from commercial lenders to fund their large investment plan, expecting that its implementation will spur economic growth and help maintain a manageable fiscal position.

38. In recent years, the structure of the economy has continued to shift away from banana production, with services gaining importance as a key source of growth. To remove impediments to faster tourism growth and diversification, the authorities plan to build a new airport and improve the island's road network. At the same time, they intend to upgrade the water infrastructure and build a new stadium. While the goals of the proposed public investment program merit support from the international community, serious questions arise about the scale, funding, and phasing of this program.

39. Even with the generous assistance already promised to Dominica by donors, the large scale of the financing required to implement these projects would result in a doubling of the external public debt. At the same time, the large portion of borrowing being contracted on commercial terms will contribute to a sharp increase in public debt service obligations. Implementation of the public investment program, as presently conceived, would greatly complicate fiscal management and, in the absence of strong adjustment measures, the government's ability to meet its commitments would be compromised.

40. Given the firm determination of the authorities to build a new airport, it would be essential to bring the public investment program to a realistic scale, by foregoing the construction of the stadium and reassessing the airport project. At the same time, it would be important to minimize borrowing on commercial terms by securing greater participation of multilateral lending institutions and donors. To this end, the authorities would need to work with such institutions to ensure that the design and implementation of the airport project meet high standards. 
41. In addition to streamlining the public investment program, the early adoption of fiscal measures would be necessary to maintain soundness in the public finances. Even the construction of a downsized airport would likely result in a significant rise in public debt and debt service. In the absence of adjustment measures, government saving would decline further, thereby compromising the government's ability to address other investment needs following the completion of the airport.

42. Efforts to increase public saving should focus mainly on restraining government current spending. In particular, it will be essential to reduce the government wage bill in relation to GDP through wage moderation and a freeze on the size of the civil service. Asso, it will be important to achieve economies in spending on goods and services, and to check the growth of transfers.

43. Improvements in tax administration and other steps to raise revenue are also in order. In particular, the staff welcomes the authorities' intention to replace a number of indirect taxes with a value added tax in order to improve the efficiency of the tax system. It would be important to intensify preparations for the early implementation of a tax reform that also would include a further reduction in import duties and a substantial streamlining of tax exemptions. Tax reform would need to be supported by the stricter enforcement of the tax code and the timely application of penalties.

44. A more determined pursuit of the structural reform agenda would help increase economic efficiency, support growth, and buttress the public finances. In particular, a firm timetable for privatizing the National Commercial Bank should be established, the state monopoly on the importation and distribution of selected commodities abolished, price controls eliminated, and further import tariff reductions expedited.

45. It will be important to maintain close surveillance over the financial system. Strict monitoring of bank portfolios and compliance with provisioning requirements must remain a priority, and uniformity of treatment across classes of institutions should be ensured. Accordingly, supervision of the nonbank financial institutions should be strengthened, particularly by tightening loan classification and other standards and transferring the mandate to supervise credit unions to the ministry of finance. In addition, close vigilance needs to be exercised over the offshore financial institutions. In the context of low inflation, the floor on the passbook saving rate may contribute to high real lending rates, and the authorities would be well advised to work with their ECCB partners toward its elimination.

46. The present exchange rate arrangement has served Dominica well. However, to safeguard international competitiveness, the authorities will need to intensify efforts to control costs, particularly wages.

47. Dominica's external position is vulnerable to shocks. In order to strengthen its production base, sizable external assistance for improving infrastructure will be needed over the medium term, which will depend on the pursuit of prudent economic policies, particularly 
policies that increase public saving. The staff commends the authorities' preparation of a medium-term economic strategy paper setting forth their objectives and policies for the period ahead. This exercise ought to be updated yearly, specifying in detail an investment program that can be supported by the international community

48. Dominica has made some progress in the provision of core statistics to the Fund, despite its limited resources. However, data deficiencies continue to hamper surveillance, and additional efforts are needed to improve data on national accounts, government finances and the labor markets. The staff encourages the authorities to provide adequate resources to the statistical units, and in particular, to strengthen the staffing of the Central Statistical Office. This would establish a solid foundation for effectively absorbing technical assistance in statistics.

49. It is recommended that the next Article IV consultation with Dominica be held on the standard 12-month cycle. 
Table 1. Dominica: Selected Economic and Financial Indicators

\begin{tabular}{|c|c|c|c|c|c|c|}
\hline & 1994 & 1995 & 1996 & 1997 & $\begin{array}{l}\text { Prel. } \\
1998 \\
\end{array}$ & $\begin{array}{l}\text { Proj. } \\
1999 \text { 1/ }\end{array}$ \\
\hline \multicolumn{7}{|c|}{ (Avunual percent change) } \\
\hline Reat GDP & 2.1 & 1.6 & 3.1 & 2.0 & 3.5 & 3.5 \\
\hline GDP deflator & 6.0 & 2.4 & 2.6 & 1.4 & 1,6 & 1.6 \\
\hline Consumer prices (end of period) & -0.2 & 1.4 & 2.0 & 2.2 & 1.5 & 1.6 \\
\hline \multicolumn{7}{|l|}{ Bariana sector indicators } \\
\hline Output (in constant EC dollars) & -24.7 & .12 .5 & -3.9 & -8.7 & .11 .8 & -2.2 \\
\hline Number of growers & -16.2 & -9.8 & -12.0 & -4.4 & -18.6 & $\ldots$ \\
\hline Net foreign assets of the financial system 2 & -9.9 & 12.4 & 7.9 & -2.0 & 7,0 & 0.0 \\
\hline Money (M2) & 4.0 & 23.1 & 2.0 & 3.5 & 6.9 & 8.1 \\
\hline $\begin{array}{l}\text { Net domestic assets of the financial system } 2 / \\
\text { Of which: }\end{array}$ & 14.0 & 10.7 & -5.9 & 5.5 & -0.1 & 8.1 \\
\hline Credit to the publie sector (net) & 10.1 & -0.8 & -1.7 & 1.6 & -2.5 & 1.7 \\
\hline Credit to the nonfinancial private sector & 8.1 & 11.0 & 3.8 & 6.1 & 7.6 & 7.5 \\
\hline Merchandise exports, f.o.b. & -2.2 & 5.0 & 4.4 & 1.9 & 16.4 & 5.6 \\
\hline Merchandise imports, f.o.b. & 4.1 & 7.7 & -2.9 & 3.8 & 3.2 & 13.6 \\
\hline Terins of trade & 4.3 & 0.1 & -3.1 & 3.7 & 0.0 & $\ldots$ \\
\hline Real effeclive exchange rate 3 / & -6.7 & -3.2 & 0.9 & 6.6 & .2 .7 & 2.6 \\
\hline \multicolumn{7}{|c|}{ (In millions of U.S. dollars) } \\
\hline \multicolumn{7}{|l|}{ Balance of payments } \\
\hline Merchandise exports, fo.b. & 47.9 & 50,3 & 52.5 & 53.5 & 62.3 & 65.8 \\
\hline Merchandise imports, f.o.b. & 95.8 & 103.2 & 100.2 & 104.0 & 107.3 & 121.9 \\
\hline Curretit account & -33.3 & -38.1 & -30.1 & -22.6 & -18.2 & -32.9 \\
\hline Capital account (including errors and omissions) & 28.9 & 45.1 & 30.9 & 23.3 & 22.0 & 34.5 \\
\hline Overall balance & -4.4 & 7.0 & 0.8 & 0.7 & 3.8 & 2.2 \\
\hline \multicolumn{7}{|c|}{ (In percent of GDP) } \\
\hline Gross domestic investment & 26.9 & 32.4 & 29.7 & 30.0 & 30.0 & 34.1 \\
\hline Gross national saving & 11.4 & 15.3 & 16.9 & 20.7 & 23.0 & 22.1 \\
\hline \multirow[t]{2}{*}{ Foreign saving 4/ } & 15.5 & 17,0 & 12.8 & 9.3 & 7.0 & 12.0 \\
\hline & $\underline{1994 / 95}$ & $\underline{1999 / 96}$ & $1996 / 97$ & $1997 / 98$ & $\begin{array}{c}\text { Prel. } \\
\underline{1998 / 99}\end{array}$ & $\begin{array}{c}\text { Proj. } \\
1999 / 001\end{array}$ \\
\hline $\begin{array}{l}\text { Central government finanes } 5 / \\
\text { Current account balance }\end{array}$ & 0.0 & 1.6 & 0.6 & 1.1 & 0.8 & -0.8 \\
\hline Overall balance & -5.7 & -0.4 & -0.8 & -4.6 & -3.8 & -10.4 \\
\hline \multicolumn{7}{|l|}{ Conswlidated pablic sector finances $\mathbf{5}$} \\
\hline Revenue and grants & 38.6 & 41.0 & 44.3 & 37.3 & 37.6 & 38.7 \\
\hline Current revenue & 31.2 & 31.6 & 34,2 & 34.7 & 33.9 & 33.9 \\
\hline Capital revenue & 1.9 & 2.5 & 1.4 & 0.5 & 0.7 & 0.7 \\
\hline Grants & 5.5 & 6.9 & 8.7 & 2.1 & 3.0 & 4.1 \\
\hline Expenditure & 43.0 & 38.7 & 43.8 & 40.0 & 40.1 & 47.7 \\
\hline Currant & 30.6 & 27.5 & 32.1 & 30.7 & 30.9 & 31.6 \\
\hline Capital & 12.4 & 11.2 & 11.7 & 9.3 & 9.2 & 16.1 \\
\hline Current account balance & 0.6 & 4.1 & 2.1 & 4.0 & 3.0 & 2.3 \\
\hline Overall balance & -4.4 & 2.3 & 0.5 & -2.7 & -2.5 & -9 \\
\hline Tolal financing & 4.4 & -2.3 & -0.5 & 2.7 & 2.5 & 9.0 \\
\hline Extemual & 0.9 & 0.1 & -0.2 & 0.6 & 0.4 & 8.8 \\
\hline Domestic & 2.9 & -2.4 & -2.7 & 1.3 & 2.1 & 0.2 \\
\hline Privatization & 0.6 & 0.0 & 2.4 & 0.8 & 0,0 & 0.0 \\
\hline Gross public sector debt (end of period) 5 / & 75.5 & 68.4 & 65.5 & 57.7 & 59.0 & 83.8 \\
\hline External & 47.6 & 44.1 & 41.7 & 35.0 & 32.7 & 98.7 \\
\hline Domestic & 27.9 & 24.3 & 23.8 & 22.7 & 26.3 & 25.1 \\
\hline
\end{tabular}

Sources: Dominica authorities; and Fund staff estimates and projections.

1/ Based on the authorities' plans.

$2 /$ Change relative to the stock of $\mathrm{M} 2$ at the beginning of the periad.

3/ The figure for 1999 correrponds to 12-month period ended June.

4/ External current account balance with the sign reversed

$5 f$ Fiscal year starts July 1. 
Table 2. Dominica: Consolidated Accounts of the Public Sector

(In pereent of GDP)

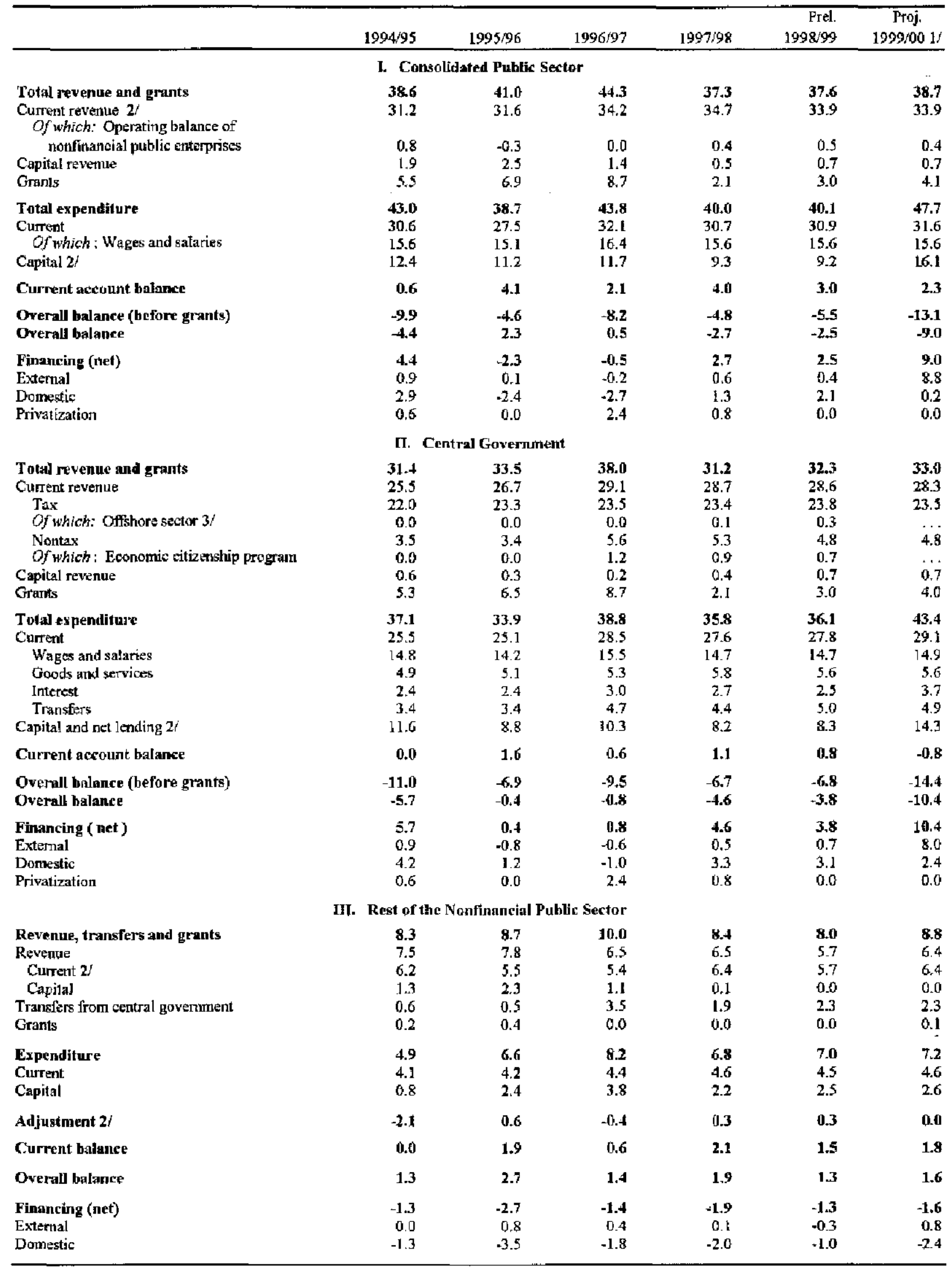

Sources: Ministry of Finance; and Fund staff estimates and projections.

1/ Based on the authorities' plans.

2/ Includes adjustment to reconcile with financing data.

3. Fees and licenses for offshore banks, gaming operations, and intamational business corporations. 
Table 3. Dominica: Public and Publicly Guaranteed External Debt 1/

\begin{tabular}{|c|c|c|c|c|c|c|}
\hline & $1994 / 95$ & $1995 / 96$ & $1996 / 97$ & $1997 / 98$ & $\begin{array}{r}\text { Prel. } \\
1998 / 99 \\
\end{array}$ & $\begin{array}{l}\text { Proj. } 27 \\
1999 / 00 \\
\end{array}$ \\
\hline \multicolumn{7}{|c|}{ (In millions of U.S. dollars) } \\
\hline External debt outstanding at end of year $3 /$ & 104.7 & 101.5 & 99.8 & 88.1 & 87.4 & 166.0 \\
\hline Drawings & 8.5 & 5.1 & 7.5 & 7.8 & 5.3 & 85.1 \\
\hline Scheduled debt service & 8.1 & 8.3 & 8.7 & 9.2 & 7.6 & 10.8 \\
\hline Principal & 5.8 & 5.8 & 6.3 & 6.8 & 5.2 & 6.5 \\
\hline Inlerest & 2.3 & 2.5 & 2.5 & 2.4 & 2.4 & 4.3 \\
\hline Debt service paid & 8.1 & 7.2 & 10.5 & 9.1 & 8.2 & 10.8 \\
\hline Principal 4/ & 5,8 & 4.8 & 7.9 & 6.8 & 5.6 & 6.5 \\
\hline Interest & 2.3 & 2.4 & 2.6 & 2.3 & 2.6 & 4.3 \\
\hline Debt forgiveness & 0.0 & 1.8 & 0.0 & 10.9 & 0.0 & 0.0 \\
\hline Change in arrears & 0.0 & 1.2 & -1.9 & 0.1 & -0.5 & 0.1 \\
\hline Valuation adjustment & 5.3 & -1.7 & $-1,3$ & -1.8 & -0.4 & 0.0 \\
\hline Stock of arrears (end of year) & 1.2 & 2,4 & 0.5 & 0.6 & 0.1 & 0.2 \\
\hline Principal & 1.1 & 2.1 & 0.4 & 0.4 & 0.1 & 0.1 \\
\hline Intereșt & 0.1 & 0.3 & 0.1 & 0.2 & 0.1 & 0.1 \\
\hline \multicolumn{7}{|c|}{ (In percent; unless othenvise indicated) } \\
\hline \multicolumn{7}{|l|}{ Memorandum items: } \\
\hline Extenal debt /GDP & 47.6 & 44,1 & 41.7 & 35.0 & 32.7 & 58.7 \\
\hline Stock of arrears/GDP & 0.5 & 1.0 & 0.2 & 0.2 & 0.0 & 0.1 \\
\hline $\begin{array}{l}\text { Scheduled debt service/exports of } \\
\text { goods and nonfactor services }\end{array}$ & 7.5 & 7.1 & 6.6 & 6.4 & 5.0 & 6.7 \\
\hline Average interest rate (percent per annum) & 1.7 & 2.0 & 2.3 & 1.6 & 2.9 & 4.4 \\
\hline GDP at market prices (millions of US $\$$ ) & 219.7 & 230.2 & 239.6 & 251.5 & 267.1 & 282.8 \\
\hline
\end{tabular}

Sources: Ministry of Finance; and Fund staff estimates and projections.

1/ Excludes atrears on contributions to regional organizations, which stood at US $\$ 2,1$ million $(0,8$ percent of GDP) at end-June 1999.

2/ Projection based on the anthorities' plans.

3/ The decline in $1997 / 98$ was aided by the substantial debt forgiveness (US\$10.9 million) granted in October 1997 by the British government to Dominica under the debt agreements reached at the Commonwealth conference (Mauritius mandate).

4/ Excludes debt forgiveness. 
Table 4. Dominica: Summary Balance of Payments

\begin{tabular}{|c|c|c|c|c|c|c|}
\hline & 1994 & 1995 & 1996 & 1997 & $\begin{array}{l}\text { Prel. } \\
1998 \\
\end{array}$ & $\begin{array}{l}\text { Proj. } \\
1999 \mathrm{l} / \mathrm{f}\end{array}$ \\
\hline \multicolumn{7}{|c|}{ (In millions of U.S. dollars) } \\
\hline Current account balance & $-\mathbf{3 3}, \mathbf{3}$ & -38.1 & $-30,1$ & -22.6 & -18.2 & -32.9 \\
\hline Trade balance & -47.9 & -52.9 & -47.7 & -50.5 & -45.0 & -56.1 \\
\hline Merchandise exports (f.o.b.) & 47.9 & 50.3 & 52.5 & 53.5 & 62.3 & 65.8 \\
\hline Bananas & 20.5 & 16,7 & 16.5 & 15.4 & 13.7 & 13.4 \\
\hline Other & 27.4 & 33.6 & 36.0 & 38.1 & 48.6 & 52.4 \\
\hline Merchandise imports (f.o.b.) & 95.8 & 103.2 & 100.2 & 104.0 & 107.3 & 121.9 \\
\hline Net nonfactor services (NFS) & 18.4 & 20.2 & 26.2 & 34.1 & 34.2 & 31.1 \\
\hline Exports of NFS & 57.9 & 61.3 & 71.0 & 85.3 & 84,6 & 88.3 \\
\hline Travel & 37.4 & 41.5 & 46.3 & 50.3 & 46.8 & 47.7 \\
\hline Other & 20.5 & 19.8 & 24.7 & 35,0 & 37.7 & 40.7 \\
\hline Jmports of NFS & 39.5 & 41.1 & 44.8 & 51.2 & 50.4 & 57.2 \\
\hline Net factor income from abroad & -10.9 & -13.3 & -18.8 & -16.7 & -17.8 & -18.9 \\
\hline Private sector & .10 .0 & -12.0 & -17.1 & $-15,0$ & -16.3 & -17.2 \\
\hline Public sector & -0.9 & -1.4 & -1.7 & -1.6 & -1.6 & -1.7 \\
\hline Net current transfers & 7.1 & 7.9 & 10.2 & 10.5 & 10.4 & 10.9 \\
\hline Private sector & 6.8 & 9.2 & 10.4 & 9.4 & 9.6 & 10.1 \\
\hline Public sector & 0.3 & -1.3 & -0.2 & 1.1 & 0.8 & 0.8 \\
\hline Capital and financial account & 28.9 & 45.1 & 30.9 & 23.3 & 22,0 & 35.1 \\
\hline Public sector & 5.8 & 24.7 & 19.7 & 16.9 & 12.1 & 22.7 \\
\hline Transfers & 5.8 & 22.1 & 20.9 & 9.3 & 11.5 & 9.8 \\
\hline Privatization & 0.0 & 1,3 & 0.0 & 8.0 & 0.0 & 0.0 \\
\hline Net borrowing & 0.9 & 1.6 & -1.5 & -9.2 & 1.0 & 39.4 \\
\hline Disbursements & 6.1 & 7.4 & 6.6 & 9.0 & 6.3 & 45,3 \\
\hline Amortization 1/ & 5.2 & 5,8 & 8.1 & 18.2 & 5.2 & 5.9 \\
\hline Repayments to IMF & -0.7 & -0.7 & -0.8 & -0.6 & 0,0 & 0.0 \\
\hline Change in arrears & 0.1 & 0.8 & -0.1 & -0.9 & -0.4 & 0.0 \\
\hline Change in government assets abroad & -0.3 & -0.5 & $-0,6$ & -0.6 & 0.0 & -26.5 \\
\hline Rescheduling and debt forgiveness & 0.0 & 0,0 & 1.8 & 10,9 & 0.0 & 0.0 \\
\hline Private sector & 23.1 & 20.4 & 11.2 & 6.4 & 9.9 & 12.4 \\
\hline Transfers & 2.8 & -2.7 & -1.4 & 2.3 & 2.4 & 2.6 \\
\hline Other & 20.3 & 23.1 & 12.6 & 4.1 & 7.4 & 9.8 \\
\hline Direct investment & 22.6 & 52.8 & 178 & 12.9 & 8.7 & 7.6 \\
\hline Commercial banks & 6.0 & -6.5 & -9.8 & 3,4 & $-6,0$ & 2.2 \\
\hline Other (including errors and omissions) & -8.2 & -23.2 & 4.6 & -12.2 & 4.8 & 0.0 \\
\hline Overall balance & -4.4 & 7.0 & 0.8 & 0.7 & 3.8 & 2.2 \\
\hline Change in (imputed) official reserves (increase -) & 4.4 & -7.0 & -0.8 & -0.7 & -3.8 & -2.2 \\
\hline \multicolumn{7}{|l|}{ Memorandum items: } \\
\hline Net imputed international reserves (end of period) & 15.4 & 22.4 & 23.2 & 23.9 & 27.7 & 29,9 \\
\hline External public debt outstanding (end of period) & 98.6 & 103.0 & 102.5 & 88.9 & 90.0 & 126.7 \\
\hline \multicolumn{7}{|c|}{ (In percent of GDP) } \\
\hline Current account balance & -15.5 & -17.0 & -12.7 & -9.3 & -7.0 & -12.0 \\
\hline Trade balance & -22.2 & -23.6 & -20.2 & -20.8 & -17.3 & -20.5 \\
\hline Merchandise exports (fo.b.) & 22.2 & 22.5 & 22.2 & 22.0 & 23.9 & 24.0 \\
\hline Merchandise imports (f,o.b.) & 44.5 & 46.1 & 42.4 & 42.9 & 41.2 & 44.5 \\
\hline Public sector net borrowing & 0.4 & 0.7 & $-0,6$ & -3.8 & 0.4 & 14.4 \\
\hline Private sector net financial inflows & 9.4 & 10.3 & 5.3 & 1.7 & 2,9 & 3.6 \\
\hline Overall balance & -2.1 & 3,1 & 0.3 & 0.3 & 1.5 & 0.8 \\
\hline Current account balance incl. capital transfers & -11.5 & -8.4 & -4.5 & -4.5 & -1.6 & -7.5 \\
\hline GDP at market prices (millions of US dollars) & 215.4 & 224,0 & 236.4 & 242.7 & 260.4 & 273.8 \\
\hline
\end{tabular}

Sources: Eastem Caribbean Central Bank (ECCB); and Fund staff estimates and projections.

1/ Based on the authorities' plans. 
Table 5. Dominica : Summary Accounts of the Banking System

\begin{tabular}{|c|c|c|c|c|c|c|c|c|}
\hline & \multicolumn{4}{|c|}{ Dec- } & \multirow{2}{*}{$\begin{array}{l}\text { June } \\
1998\end{array}$} & \multirow{2}{*}{$\begin{array}{c}\text { Dec. } \\
1998\end{array}$} & \multirow{2}{*}{$\begin{array}{c}\text { June } \\
1999\end{array}$} & \multirow{2}{*}{$\begin{array}{l}\text { Dec. } \\
19991 /\end{array}$} \\
\hline & 1994 & 1995 & 1996 & 1997 & & & & \\
\hline \multicolumn{9}{|c|}{ (In militions of Eastem Caribbean dollars, end of period) } \\
\hline \multicolumn{9}{|c|}{ I. Consolidated Bonking System } \\
\hline Net foreign assels & 7.2 & 43.5 & 71.9 & 64.7 & 82.9 & 91.2 & 86.7 & 91.2 \\
\hline $\begin{array}{l}\text { Net domestic assets } \\
\text { Net credit to the nonfinancial public sector } \\
\text { Net credit to nonbank financial institutions } \\
\text { Credit to the nonfinanejal privale sector } \\
\text { Other items (net) }\end{array}$ & $\begin{array}{r}286.1 \\
50.4 \\
-30.4 \\
312.5 \\
-46.4\end{array}$ & $\begin{array}{r}317.5 \\
47.9 \\
-31.7 \\
344.6 \\
-43.3\end{array}$ & $\begin{array}{r}296.2 \\
41.7 \\
-54.0 \\
358.5 \\
-50.1\end{array}$ & $\begin{array}{r}316.3 \\
47.5 \\
-63.3 \\
381.0 \\
-48.9\end{array}$ & $\begin{array}{r}308.8 \\
47.5 \\
-67.8 \\
394.0 \\
-64.9\end{array}$ & $\begin{array}{r}316.0 \\
37.9 \\
-62.5 \\
410.0 \\
-69.4\end{array}$ & $\begin{array}{r}342.1 \\
57.8 \\
-59.4 \\
415.6 \\
-71.9\end{array}$ & $\begin{array}{r}348.8 \\
44.8 \\
-67.5 \\
440.4 \\
-68.9\end{array}$ \\
\hline Broad money: $2 f$ & 293.3 & 361.0 & 368.1 & 381.0 & 391.6 & 407.2 & 428.8 & 440.0 \\
\hline \multicolumn{9}{|c|}{ II. Operations of the Eastern Cariblean Central Bank } \\
\hline Improted net international reserves & $\$ 1.7$ & 60.5 & 62.6 & 64.5 & 63.6 & 74.7 & 76.3 & 80.7 \\
\hline Net domestic assets & 19.4 & 14.5 & 12.3 & 11.9 & 13.1 & 11.1 & 11.0 & 11.1 \\
\hline Monetary base & 61.1 & 74.8 & 74.9 & 76.4 & 76.7 & 85.8 & 873 & 91.8 \\
\hline Cuntency in circulation & 24.5 & 29.2 & 28.5 & 28.2 & 24.5 & 29.1 & 30.7 & 31.5 \\
\hline Commercial bank reserves & 36.7 & 45.6 & 46.4 & 48.2 & 52.1 & 56.7 & 56.6 & 60.4 \\
\hline \multicolumn{9}{|c|}{ III. Commescial Banks } \\
\hline Net forcign assets & -34.5 & -17.0 & 9.3 & 0.2 & 19.3 & 16.5 & 10.4 & 10.5 \\
\hline Net elnims on ECCB & 31.5 & 45.9 & 46.5 & 44.9 & 50.3 & 53.4 & 58.7 & 60.4 \\
\hline Net domestic assets & 271.9 & 303.0 & 283.7 & 307.6 & 297.5 & 308.2 & 328.9 & 337.6 \\
\hline Net credil to the nonfinamcial public sector & 30.9 & 33.6 & 29.4 & 35.6 & 34.4 & 26.8 & 46.8 & 33.7 \\
\hline Net credit to nonbank financial institutions & -30.4 & -31.7 & $-\$ 4.0$ & .63 .3 & -67.8 & -62.5 & -59.4 & -67.5 \\
\hline Credit to the nogufinancial private sector & 312.5 & $\$ 44.6$ & 358.5 & 381.0 & 394.0 & 410.0 & 415.6 & 440.4 \\
\hline Other (net) & -41.2 & -43.6 & -50.2 & -45.7 & -63.1 & -66.1 & -74.1 & -69.0 \\
\hline Privat e sector deposits $2 f$ & 268.8 & 331.8 & 339.6 & 352.7 & 367.1 & 378.0 & 398.1 & 408.5 \\
\hline \multicolumn{9}{|c|}{ IV. Consnlidated Eanking System } \\
\hline \multicolumn{9}{|c|}{ (Annual pertentage change) } \\
\hline Credit to the nonfinancial private sector & 7.9 & 10.3 & 4.0 & 6.3 & 6.5 & 7.6 & 5.5 & 7.4 \\
\hline Broad money $2 /$ & 4.0 & 23.1 & 2.0 & 3.5 & 4.0 & 6.9 & 9.5 & 8.1 \\
\hline \multicolumn{9}{|c|}{ (Contributions to liquidity growth) 3 / } \\
\hline Net foreign assets & -9.9 & 12.4 & 3.9 & $-2,0$ & -0.1 & 7.0 & 1.0 & 0.0 \\
\hline Net domestic assets & 14.0 & 10.7 & -5.9 & 5.5 & 4.1 & -0.1 & 8.5 & 8.1 \\
\hline Net credit to the nonfinarcial public sector & 10.1 & -0.8 & -1.7 & 1.6 & 2.5 & -2.5 & 2.6 & 1.7 \\
\hline Credit to the nonfinamcial private sector & 8.1 & 11.0 & 3.8 & 6.1 & 6.4 & 7.6 & 5.5 & 7.5 \\
\hline \multicolumn{9}{|l|}{ Memorandum ttems: } \\
\hline Velocity 4 / & 2.0 & 1.7 & 1.7 & 1.8 & 1.8 & 1.8 & 1.8 & 1.8 \\
\hline \multicolumn{9}{|l|}{ Interest rales 5/ } \\
\hline Deposits & 4.2 & 4.4 & 4.7 & 4.9 & 4.2 & 4.0 & 4.0 & $\cdots$ \\
\hline Lending & 12.2 & 12.0 & 11.8 & 12.0 & 11.4 & 11.2 & 11.4 & $\ldots$ \\
\hline
\end{tabular}

Sources: Data provided by the Eastern Caribbean Central Bank; and Fund staff estimates.

1/ Based on authorities' plats.

2/ Including deposits denominated in U.S. dollars.

3/ Change relative to broad money at the beginning of the period.

4/ Nominal GDP at markel prices divided by the a verage of the year-end stock of broad money for the current and previous year.

5/ Commetcial banks; weighted averages of end-ycar rates per annum. 
Table 6. Dominica: Medium-Term Scenarios

Pret. 1999-2004 Average Modified 2005-2009 Average Modified

$1998 \quad$ Baseline Baseline Altemative Baseline Baseline Alternative

(Annual percentage change; unless otherwise indicated)

National income and prices

GDP at constant 1990 market prices

Consumer prices (end period)

Monetary indicators

Net foreign assets of the banking system (in percent of GDP)

Credit to private sector (in real terms)

$\begin{array}{rrrrrr}4.8 & 3.5 & 4.6 & 4.3 & 3.5 & 4.5 \\ 2.4 & 1.7 & 1.9 & 1.9 & 1.6 & 2.0 \\ & & & & & \\ 11.1 & 11.8 & 10.7 & 11.8 & 11.2 & 7.2 \\ 6.0 & 4.1 & 3.0 & 5.4 & 4.4 & 0.4\end{array}$

\section{Saving-investment}

Gross national saving

Domestic saving

Private sector

Public sector

Net factor income

Net current transfers

Gross domestic investment

Private sector

Public sector

23.0

25.8

22.4

3.5

$-6.8$

4.0

30.0

22.2

7.9

Balance of payments

Exterual current account

Merchandise exports (f o.b.)

Of which: Bananas

Merchandise imports (f.o.b.)

Services, income, and transfers account

Capital and financial account

Overall balance $1998 / 99$

Public sector finances 1/

Interest expenditure

Saving

Capital expenditure

Overall balance

Financing

Foreign

Domestic

Privatization

Gross debt (end of period)

Central government

Public sector

$2.9 \quad 0.4$

\section{8}

66.3

$\begin{array}{rrrr}-7.0 & -8.9 & -16.6 & -12.0 \\ 23.9 & 24.6 & 24.5 & 24.5 \\ 5.3 & 4.2 & 4.1 & 4.1 \\ 41.2 & 44.0 & 47.7 & 45.2 \\ 10.3 & 10.5 & 6.7 & 8.8 \\ 8.5 & 9.4 & 17.3 & 12.6 \\ 1.5 & 0.6 & 0.7 & 0.7\end{array}$

Prel.

$\begin{array}{rrr}22.3 & 18.3 & 21.1 \\ 25.3 & 22.9 & 24.8 \\ 22.4 & 22.4 & 22.4 \\ 2.9 & 0.5 & 2.5 \\ -6.9 & -8.5 & -7.7 \\ 4.0 & 3.9 & 4.0\end{array}$

$31.2 \quad 34.9$

$21.9 \quad 21.3$

$9.4 \quad 13.7$

33.1

1999/00-2003/04 Average

Baseline Baseline Alternative

2.5

3.1

5.1

$\begin{array}{ll}9.4 & 14.7\end{array}$

$-2.3-8.6$

$2.3 \quad 8.6$

$1.8 \quad 6.3$

$0.4 \quad 2.3$

$0.0 \quad 0.0$

0.0

51.3

68.6
81.5
92.5
21.3

11.9

12.0

4.1

45.2

8.8

0.7

21.3

16.6

21.5

22.4

$\begin{array}{rr}2.6 & -0.8\end{array}$

$-7.6 \quad-8.6$

$3.9 \quad 3.8$

$30.4 \quad 30.0$

$21.3 \quad 21.9$

9.18 .1

$-9.0 \quad-13.2$

$26.3 \quad 26.0$

$3.0 \quad 2.7$

$46.8 \quad 49.1$

11.59 .9

$9.5 \quad 13.9$

$0.5 \quad 0.6$

2004/05-2008/09 Average

Modified

Baseline Baseline Alternative

$\begin{array}{rr}3.4 & 6.1 \\ 2.6 & -0.8 \\ 9.0 & 8.0 \\ -2.3 & -4.8 \\ 2.3 & 4.8 \\ 2.7 & 0.5 \\ -0.4 & 4.3 \\ 0.0 & 0.0\end{array}$

3.8

2.4

12.4

$-4.3$

4.3

4.0

$-0.3$

0.6

0.0

0.0

60.7

89.2

60.8

63.190 .9

Sources: Ministry of Finance; and Fund staff estimates and projections.

1/ Fiscal year starts on July 1 . 
Table 7: Dominica: Cost and Funding Scenarios for Key Government Projects

(In millions of U.S. dollars; unless otherwise indicated)

\begin{tabular}{lrr}
\hline & \multicolumn{2}{c}{ Scenarios } \\
\cline { 2 - 3 } & $\begin{array}{c}\text { Modified } \\
\text { Baseline 1/ }\end{array}$ & Alternative 2/ \\
\hline 1. Cost & 130.9 & 90.9 \\
2. Funding & 130.9 & 90.9 \\
Privatization 3/ & 0.0 & 10.0 \\
Grants 4/ & 32.0 & 32.0 \\
Loans & 98.9 & 48.9 \\
$\quad$ Borrowing & 98.9 & 57.4 \\
$\quad$ Amortization 5/ & 0.0 & 8.4 \\
3. Terms of borrowing & & \\
Interest rate (percent) 6/ & & 7.7 \\
Maturity (years) 6/ & 8.5 & 4.8 \\
Grace period (years) 6/ & 14.0 & 49.6 \\
Net present value of debt service 7/ & 3.4 & \\
\hline
\end{tabular}

Sources: Ministry of Finance; and Fund staff estimates.

1/ Involves building both airport and stadium as currently envisioned by the authorities.

2/ Involves building a somewhat smaller airport only.

3/ Proceeds from assumed sale of government shares in National Commercial Bank and Dominica Electricity Services, Ltd.

4/ Grants that the authorities expect will be disbursed by Taiwan, Province of China and the European Union by the end of the projected construction period (June 2003).

5/ Early redemption of part of the bonds placed with Trinidad and Tobago banks. An assumed loan for US\$10 million by multilateral banks would be used in part to fund this pre-payment.

$6 /$ Average of loans, weighted by principal.

7/ Evaluated at discount rate of 8 percent. 
Table 8. Dominica: Medium-Term Public and Publicly Guaranteed External Debt

\begin{tabular}{|c|c|c|c|c|c|c|c|}
\hline & Prel. & & Project & ons (alter & lative scen & ario) & \\
\hline & $1998 / 99$ & $1999 / 2000$ & $2000 / 01$ & $2001 / 02$ & $2002 / 03$ & $2003 / 04$ & $2004 / 05$ \\
\hline & (In milli & s of U.S. do & ars) & & & & \\
\hline External debt outstanding at end of year & 87.4 & 126.4 & 138.4 & 142.9 & 152.6 & 162.1 & 172.7 \\
\hline Drawings & 5.3 & 45.6 & 18.6 & 19.0 & 17.8 & 17.2 & 18.9 \\
\hline Scheduled debt service & 7.6 & 10.9 & 12.3 & 20,6 & 14.4 & 13.9 & 14.4 \\
\hline Principal & 5.2 & 6.6 & 6.5 & 14.5 & 8.2 & 7.6 & 8.4 \\
\hline Interest & 2.4 & 4.3 & 5.8 & 6.1 & 6.2 & 6.3 & 6.0 \\
\hline Actual debt service & 8.2 & 10.9 & 12.3 & 20.6 & 14.4 & 13.9 & 14.4 \\
\hline Principal & 5.6 & 6.6 & 6.5 & 14.5 & 8.2 & 7.6 & 8.4 \\
\hline Interest & 2,6 & 4.3 & 5.8 & 6.1 & 6.2 & 6.3 & 6.0 \\
\hline Change in arrears & -0.5 & 0.1 & 0.0 & 0.0 & 0.0 & 0.0 & 0.0 \\
\hline Valuation adjustment & -0.4 & 0.0 & 0.0 & 0.0 & 0.0 & 0.0 & 0.0 \\
\hline Stock of arrears (end of year) & 0.1 & 0.2 & 0.2 & 0.2 & 0.2 & 0.2 & 0.2 \\
\hline Principal & 0.1 & 0.1 & 0.1 & 0.1 & 0.1 & 0.1 & 0.1 \\
\hline Interest & 0.1 & 0.1 & 0.1 & 0.1 & 0.1 & 0.1 & 0.1 \\
\hline (In pe & nt of GD & unless othe & wise indio & ated) & & & \\
\hline Memorandum items: & & & & & & & \\
\hline External debt outstanding/GDP & 32.7 & 44.7 & 45.8 & 44.3 & 44.4 & 44.4 & 44.4 \\
\hline $\begin{array}{l}\text { Scheduled debt service/exports of } \\
\text { goods and nonfactor services } 1 /\end{array}$ & 5.0 & 6.8 & 7.1 & 11.0 & 7.1 & 6,3 & 6.1 \\
\hline Stock of arrears/GDP & 0.0 & 0.1 & 0.1 & 0.1 & 0.1 & 0.1 & 0.1 \\
\hline Average interest rate (percent per annum) & 2.9 & 5.0 & 5.2 & 5.0 & 4.9 & 5.0 & 4.9 \\
\hline GDP at market prices (millions of US\$) & 267.1 & 282.8 & 302.2 & 322.9 & 343.3 & 365.1 & 389.1 \\
\hline
\end{tabular}

Sources: Ministry of Finance; and Fund staff estimates and projections.

1/ Increase in 2001/02 reflects a prepayment of part of the Trinidad and Tobago airport bonds. 
Table 9. Dominica: Medium-Term Balance of Payments

\begin{tabular}{|c|c|c|c|c|c|c|c|}
\hline & \multirow{2}{*}{$\begin{array}{l}\text { Prel. } \\
1998 \\
\end{array}$} & \multicolumn{6}{|c|}{ Projections (alternative scenaño) } \\
\hline & & 1999 & 2000 & 2001 & 2002 & 2003 & 2004 \\
\hline \multicolumn{8}{|c|}{ (In millions of U.S. dollars) } \\
\hline Current account balance & -18.2 & -29.7 & -43.1 & -45.4 & -41.9 & $-\mathbf{3 5 . 3}$ & -33.8 \\
\hline Trade balance & -45.0 & -53.9 & -65.3 & -69.1 & -69.7 & -70.4 & -73.1 \\
\hline Merchandise exports (f.o.b.) & 62.3 & 65.8 & 70.5 & 76.0 & 81.7 & 87.5 & 94.3 \\
\hline Bananas & 13.7 & 13.4 & 13.3 & .13 .2 & 13.0 & 12.9 & 12.8 \\
\hline Other & 48.6 & 52.4 & 57.2 & 62.8 & 68.6 & 74.6 & 81.5 \\
\hline Merchandise imports (f,o.b.) & 107.3 & 119.7 & 135.8 & 145.1 & 151.3 & 157.9 & 167.4 \\
\hline Net nonfactor services (NFS) & 34.2 & 32.1 & 32.7 & 35.9 & 40.9 & 49.2 & 54.7 \\
\hline Exports of NFS & 84.6 & 88.3 & 96.5 & $104 . I$ & 111.9 & 123.4 & 133.3 \\
\hline Travel & 46,8 & 47.7 & 52.1 & 55.3 & 58.6 & 65.4 & 70.0 \\
\hline Other & 37.7 & 40.7 & 44.4 & 48.8 & 53.3 & 58,0 & 63.3 \\
\hline Imports of NFS & 50.4 & 56.2 & 63.8 & 68.1 & 71,0 & 74.1 & 78.6 \\
\hline Net factor income from abroad & -17.8 & -18.8 & $-22,3$ & -24.6 & -26.2 & -27.9 & -30.1 \\
\hline Net current transfers & 10.4 & 10.9 & 11.7 & 12.4 & 13.1 & 13.8 & 14.6 \\
\hline Capital and financial account & 22.0 & 31.9 & 45.0 & 47.6 & 44.0 & 37,4 & 36.2 \\
\hline Public sector & 12.1 & 20.0 & 33.5 & 35,3 & 32.3 & 29.8 & 20.6 \\
\hline Transfers & 11.5 & 9.8 & 12.6 & 17.3 & 21.3 & 21.6 & 12.4 \\
\hline Privatization & 0.0 & 0.0 & 0.0 & 5.0 & 5.0 & 0.0 & 0,0 \\
\hline Net borrowing & 1.0 & 19.6 & 24.7 & 7.4 & 5,9 & 8.3 & 8.2 \\
\hline Disbursements & 6.3 & 25.5 & 31.2 & 17.9 & 17.3 & 16.2 & 16.2 \\
\hline Amortization & 5.2 & 5,9 & 6.6 & 10.5 & 11.4 & 7.9 & 8.0 \\
\hline Change in arrears & -0.4 & 0.0 & 0.0 & 0,0 & 0,0 & 0.0 & 0.0 \\
\hline Change in government assets abroad & 0.0 & -9.4 & $-3,8$ & 5.6 & 0.0 & 0.0 & 0.0 \\
\hline Private sector & 9.9 & 11.9 & 11.5 & 12.2 & 11.7 & 7.5 & 15.6 \\
\hline Overall balance & 3.8 & 2,2 & 1.9 & 2.2 & 2.1 & 2.0 & 2.3 \\
\hline Change in (imputed) official reserves (increase -) & -3.8 & -2.2 & -1.9 & -2.2 & -2.1 & -2.0 & -2.3 \\
\hline \multicolumn{8}{|l|}{ Memorandum items: } \\
\hline Net imputed international reserves (end of period) & 27.7 & 29.9 & 31.7 & 33.9 & 36.0 & 38.0 & 40.3 \\
\hline External public debt outstanding (end of period) & 90.0 & J06.9 & 132.4 & 140.7 & 147.7 & 157.4 & 167,4 \\
\hline \multicolumn{8}{|c|}{ (In percent of GDP) } \\
\hline Current account balance & -7.0 & -10.8 & -14.8 & $-14,5$ & -12.6 & -10.0 & -9.0 \\
\hline Trade balance & -17.3 & -19.7 & -22.4 & -22.1 & -20.9 & -19.9 & -19.4 \\
\hline Merchandise exports (f.o.b.) & 23.9 & 24,0 & 24.2 & 24.3 & 24.5 & 24.8 & 25.0 \\
\hline Merchandise imports (f.o.b.) & 41.2 & 43.7 & 46.5 & 46.4 & 45.4 & 44.7 & 44.4 \\
\hline Public sector net borrowing & 0.4 & 7.2 & 8.5 & 2.4 & 1.8 & 2.3 & 2.2 \\
\hline Overall balance & 1.5 & 0.8 & 0.6 & 0.7 & 0.6 & 0.6 & 0.6 \\
\hline Current account balance incl. capital transfers & -1.6 & -6.3 & -9.5 & -8.0 & -5.2 & -2.9 & -4.7 \\
\hline GDP at market prices (millions of US dollars) & 260.4 & 273.8 & 291.8 & 312.6 & 333.2 & 353.4 & 376.7 \\
\hline
\end{tabular}

Sources: Eastern Caribbean Central Bank (ECCB); and Fund staff estimates and projections. 
Figure 1. Dominica: Selected Economic Indicators
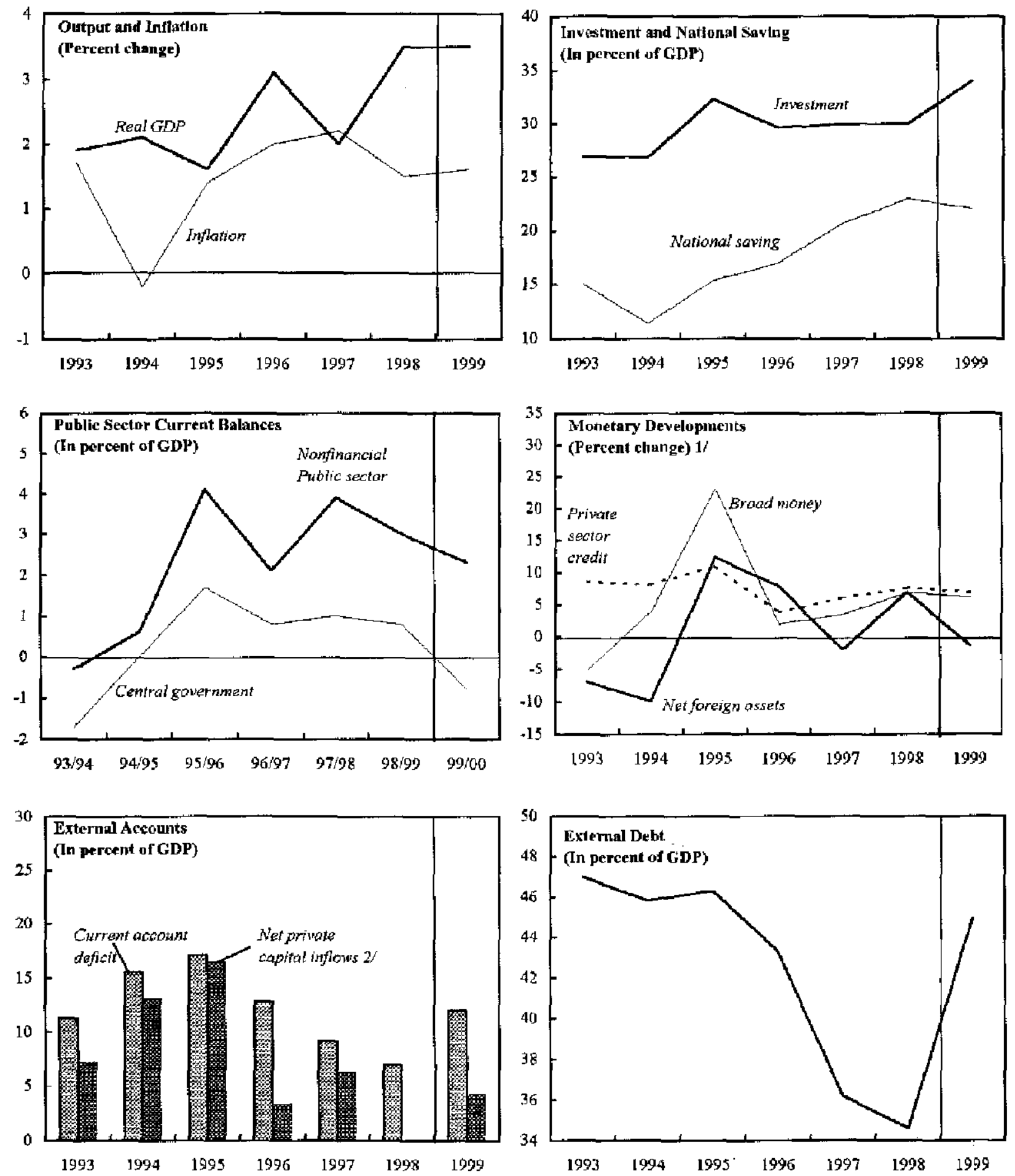

Sources: Data provided by the Dominica authorities; and Fund staff estimates and projections.

$1 /$ Change relative to broad money at the beginning of the period.

2/ Excludes transfers. 
Figure 2. Selected Small Countries: Government Taxes and Wage Bill, and Population ${ }^{1 /}$ (1997-1999)

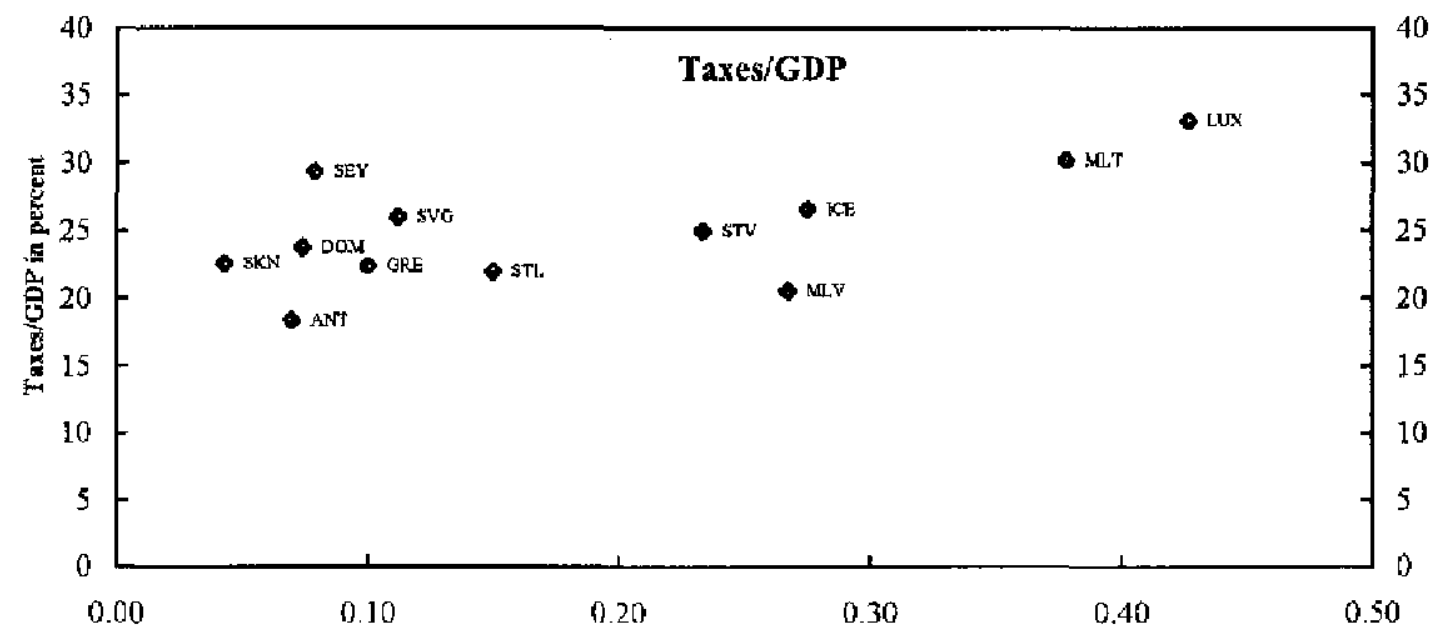

Population in millions

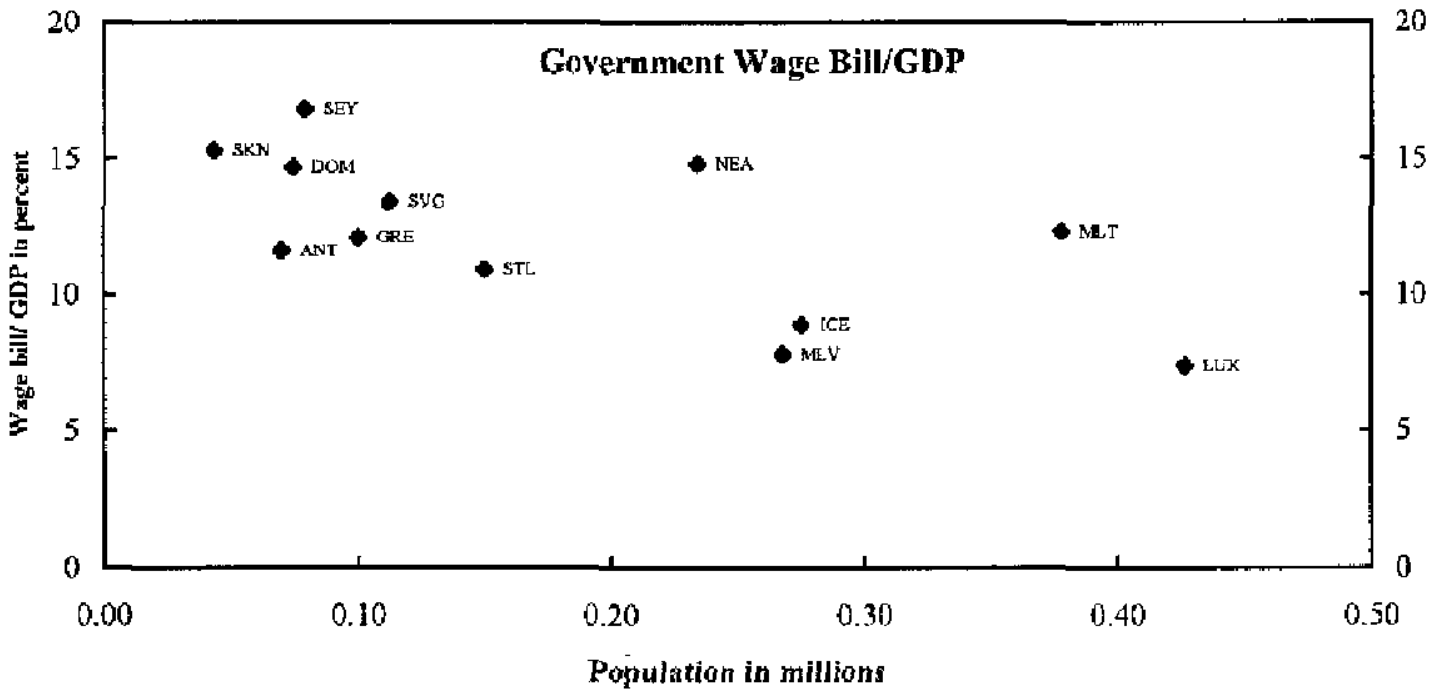

Soures: World Bank; and IMF,

1/ $\mathrm{ANT}=$ Antigua and Barbuda, DOM=Dominica, GRE=Grenada, ICE=Iceland, LUX=Luxembourg, MLV=Maldives, MLT=Malta, NEA=the Netherlands Antilles, SEY=Seychelles, SKN=St. Kitts and Nevis, STL $=$ Saint Lucia, and SVG=Saint Vincent \& the Grenadines. 
Figure 3. Dominica: Total Debt Stocks and External Debt Service
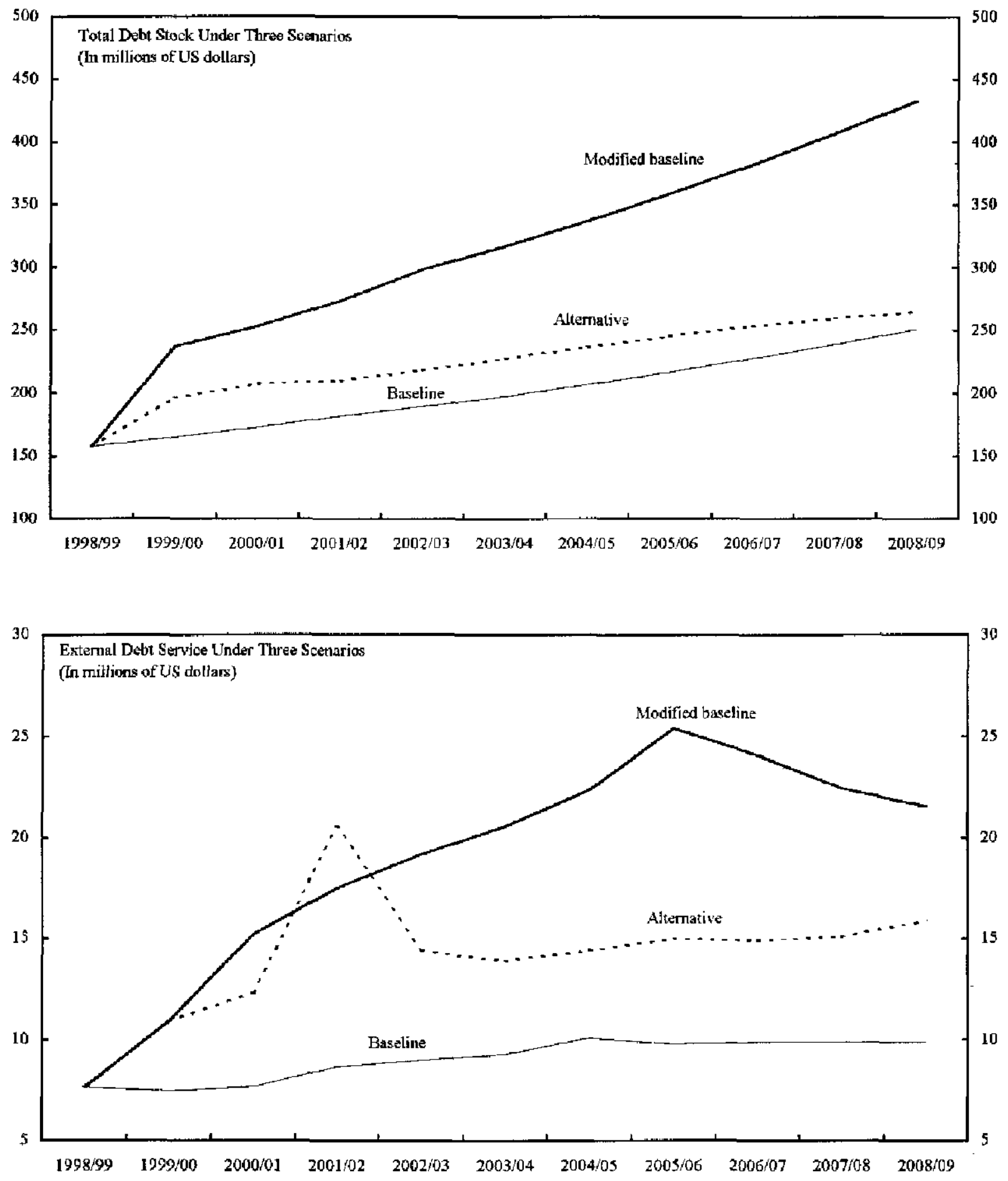

Sources: Ministry of Finance; and Fund staff estimates and projections. 
Figure 4. Dominica: Exchange Rate Developments

(Index 1990=100)

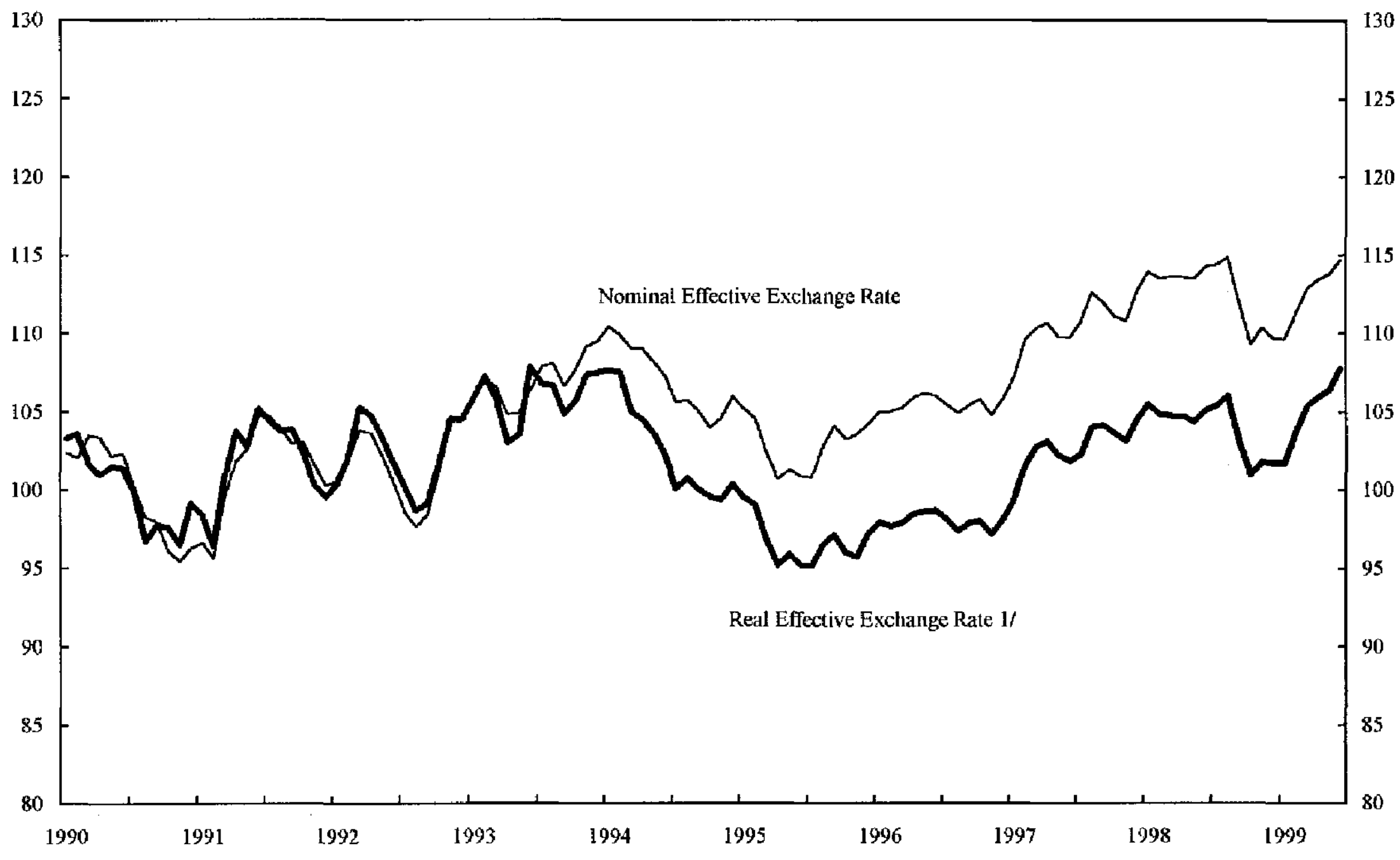

Sources: IMF Information Notice System; and Fund staff estimates and projections.

$1 /$ The rcal effective exchange rate estimated as a trade-weighted index of nominal exchange rates deflated by seasonally adjusted relative consumer prices. An increase means an appreciation. 


\section{Dominica: Fund Relations \\ (As of November 30, 1999)}

I. Membership Status: Joined 12/12/78; Article VIII

II. General Resources Account

Quota

Fund holdings of currency

Reserve position in Fund

SDR Mition

8.20

8.19

0.01

SDR Million

0.59

0.00
Percent

of Quota

100.0

99.9

0.1

Percent of

Allocation

100.0

0.1

IV. Outstanding Purchases and Loans; None,

V. Financial Arrangentents:

\begin{tabular}{|c|c|c|c|c|}
\hline Type & $\begin{array}{c}\text { Approval } \\
\text { Date }\end{array}$ & $\begin{array}{c}\text { Expiration } \\
\text { Date }\end{array}$ & \multicolumn{2}{|c|}{$\begin{array}{l}\text { Amount Drawn } \\
\text { (SDR Million) }\end{array}$} \\
\hline SAF & $11 / 26 / 86$ & $11 / 25 / 89$ & 2.80 & 2.80 \\
\hline Stand-by & $07 / 18 / 84$ & $07 / 17 / 85$ & 1.40 & 0.97 \\
\hline EFF & $02 / 06 / 81$ & $02 / 05 / 84$ & 8.55 & 8.55 \\
\hline
\end{tabular}

VI. Projected Obligations to the Fund: None.

VII. Exchange rate arrangement: Dominica is a member of the Eastern Caribbean Currency Union, which has a common central bank (the Eastern Caribbean Central Bank) and currency (the Eastern Caribbean dollar). Since July 1976, the Eastern Caribbean dollar has been pegged to the U.S. dollar at the rate of EC\$2.70 per U.S. dollar.

VII. Article IV consultation: The last Article IV consultation was concluded by the Executive Board on August 25, 1998 (EBM/98/88); the relevant documents are SM/98/20l and SM/98/204. Dominica is on the standard 12 -month cycle.

IX. Technical assistance: FAD missions visited Roseau to provide technical assistance on tax policy and administration, with special emphasis on VAT implementation (1999), on urban property taxation (1997), and on-tax policy and adrninistration, and expenditure control (1995). 


\section{Dominica: Statistical Issues}

There are a number of issues to be addressed concerning the economic data of Dominica (see the attached survey of reporting of main statistical indicators). Only the balance sheet of the consolidated commercial banks, the balance sheet of the central bank, interest rates data, and the consumer price index are provided on a regular basis. Data on other key indicators, such as exports, imports, the external current account, public sector operations, and GDP usually are provided only during missions or upon special request. An important step to improve the statistical base would be to strengthen staffing of the Central Statistics Office (CSO). This would establish a more solid foundation for effectively absorbing technical assistance in statistics.

\section{Real sector}

CPI data are provided on a timely basis. Data on nominal GDP (on a sectoral basis) are available within a few months of the end of the year. Data on employment are limited and there are no official data on producer prices or wages in the private sector.

\section{Government finance}

Dominica has fallen considerably behind in reporting government finance statistics for publication in the Government Finance Statistics Yearbook (GFSY). Some data were submitted in 1993, but the data do not conform to GFSY methodology.

Data on central government expenditure are not always complete, as some capital transactions are not conducted through the consolidated fund. Adjustments must therefore be made to arrive at a more complete total for government expenditure.

\section{Balance of payments}

Balance of payments data are provided by the Eastern Caribbean Central Bank (ECCB). Difficulties with the estimation of tourism receipts and the measurement of trade data are being addressed by the ECCB, the Central Statistical Office (CSO), and the Customs Department. The problem with obtaining current data on trade flows (exports and imports) appears to derive from technical difficulties in transferring information between the Customs Department and the CSO; the difficulties are mostly computer related. 
Dominica: Survey of Reporting of Main Statistical Indicators

(As of November 15, 1999)

\begin{tabular}{|c|c|c|c|c|c|c|c|c|c|c|c|}
\hline & $\begin{array}{c}\text { Exchange } \\
\text { Rates }\end{array}$ & $\begin{array}{l}\text { International } \\
\text { Reserves }\end{array}$ & $\begin{array}{l}\text { Reserve' } \\
\text { Base } \\
\text { Money }\end{array}$ & $\begin{array}{l}\text { Broad } \\
\text { Money }\end{array}$ & $\begin{array}{l}\text { Interest } \\
\text { Rates }\end{array}$ & $\begin{array}{l}\text { Consumer } \\
\text { Price } \\
\text { Index }\end{array}$ & $\begin{array}{l}\text { Exports/ } \\
\text { Iniports }\end{array}$ & $\begin{array}{l}\text { Curtent } \\
\text { Account } \\
\text { Balance }\end{array}$ & $\begin{array}{c}\text { Overall } \\
\text { Government } \\
\text { Balance }\end{array}$ & GDP/GNP & $\begin{array}{l}\text { External } \\
\text { Debt }\end{array}$ \\
\hline $\begin{array}{l}\text { Date of latest } \\
\text { observation }\end{array}$ & $\begin{array}{l}\text { Fixed rate } \\
\text { since } 1976\end{array}$ & $8 / 99$ & $8 / 99$ & $8 / 99$ & $8 / 99$ & $7 / 99$ & QH/99 ${ }^{1}$ & 1998 & $6 / 99$ & 1998 & $7 / 99$ \\
\hline Date received & & $11 / 1 / 99$ & $11 / 1 / 99$ & $11 / 1 / 99$ & $11 / 1 / 99$ & $9 / 10 / 99$ & $9 / 10 / 99$ & $9 / 10 / 99$ & $7 / 26 / 99$ & $9 / 10 / 99$ & $9 / 10 / 99$ \\
\hline $\begin{array}{l}\text { Pirequency of } \\
\text { data scrics }\end{array}$ & & Monthly & Monthly & Morthly & Monthly & Monthly & Monthly & Annural & Monthly & Annual & Monthly \\
\hline $\begin{array}{l}\text { Frequency of } \\
\text { reporting io IMF }\end{array}$ & & $\begin{array}{l}\text { Monthly } \\
\text { (lag of 1-2 } \\
\text { months) }\end{array}$ & $\begin{array}{c}\text { Montlly (lag } \\
\text { of } 1-2 \\
\text { months) }\end{array}$ & $\begin{array}{l}\text { Monthly } \\
\text { (lag of } 1 \cdot 2 \\
\text { montlis) }\end{array}$ & $\begin{array}{c}\text { Monthly } \\
\text { (lag of 1-2 } \\
\text { months) }\end{array}$ & $\begin{array}{l}\text { Monthly } \\
\text { (lig of } 1-2 \\
\text { months) }\end{array}$ & On request & Annual & Quarterly & Annual & On request \\
\hline Source of update & & $\mathrm{ECCB}$ & ECCB & ECCB & $\mathrm{ECCB}$ & $\begin{array}{l}\text { Central } \\
\text { Statistical } \\
\text { Office, } \\
\text { Ministry of } \\
\text { Finance }\end{array}$ & $\mathrm{ECCB}$ & $\mathrm{ECCB}$ & $\begin{array}{l}\text { Ministry } \\
\text { Of } \\
\text { Finance }\end{array}$ & $\begin{array}{l}\text { Central } \\
\text { Statistical } \\
\text { Office, } \\
\text { Ministry of } \\
\text { Finance }\end{array}$ & $\begin{array}{l}\text { Dobe Unit } \\
\text { Ministry of } \\
\text { Finance }\end{array}$ \\
\hline $\begin{array}{l}\text { Mode of } \\
\text { reporting }\end{array}$ & & E-Mail & E - Mail & E - Mail & $E \cdot$ Mail & Fax & $\begin{array}{l}\text { Mission' } \\
\text { Mail }\end{array}$ & $\begin{array}{c}\text { Mission } \\
\text { Mail }\end{array}$ & $\begin{array}{c}\text { Misssion } / \\
\text { Mail }\end{array}$ & $\begin{array}{c}\text { Mission' } \\
\text { Mail }\end{array}$ & $\begin{array}{l}\text { Mission/ } \\
\text { Mail/ Fax }\end{array}$ \\
\hline Confidentiality & & Unestricted & Unrestricted & Unrestricted & Unrestricted & Unrestricted & Unrestrieted & Unfestricted & Restricted & Unrestricted & Restricted \\
\hline Published data & & Yes & Yes & Yes & Yes & Yes & Yes & Yes & No & Yes & No \\
\hline
\end{tabular}

\footnotetext{
${ }^{1}$ Import data for most of 1998 are, however, unavailable.
} 


\section{Dominica: Stayover Tourist Arrivals in the Caribbean 1/}

(In thousands; unless otherwise specified)

\begin{tabular}{|c|c|c|c|c|c|c|c|}
\hline & 1992 & 1993 & 1994 & 1995 & 1996 & 1997 & 1998 \\
\hline Caribbean & $12,204.1$ & $13,275,8$ & $14,233.0$ & $14,468.9$ & $14,904.9$ & $15,859.0$ & $16,457,0$ \\
\hline Eastern Caribbean & 836.0 & 993.5 & $1,099.9$ & $1,035.6$ & $1,067.4$ & $1,110.9$ & $1,158.7$ \\
\hline Anguilla & 30.4 & 37.7 & 43.7 & 38.5 & 37.5 & 43.2 & 43.9 \\
\hline Antigua and Barbuda & 217.9 & 249.4 & 262.9 & 220.0 & 228.2 & 240.4 & 234.3 \\
\hline British Virgin Islands & 116.9 & 200.2 & 238,7 & 219.5 & 243.7 & 244.3 & 279.1 \\
\hline Dominica & 47.0 & 51.9 & 56.5 & 60.5 & 63.3 & 65.4 & 65.5 \\
\hline Grenada & 87.6 & 93.9 & 109.0 & 108.0 & 108.2 & 110.7 & 115.8 \\
\hline Montserrat & 17.3 & 21.0 & 21.3 & 17.7 & 8.7 & 5.1 & 7.5 \\
\hline St. Kitts and Nevis & 88.3 & 88.6 & 94.2 & 78.9 & 84.2 & 88.3 & 93.2 \\
\hline St. Lucia & 177.5 & 194.1 & 218.6 & 232.3 & 235.7 & 248.4 & 252.2 \\
\hline St. Vincent and the Grenadines & 53.1 & 56.7 & 55.0 & 60.2 & 57.9 & 65.1 & 67.2 \\
\hline $\begin{array}{l}\text { Other Caribbean } \\
\text { Of which: }\end{array}$ & $11,368.1$ & $12,282.3$ & $13,133.1$ & $13,433.3$ & $13,837.5$ & $14,748.1$ & $15,298.3$ \\
\hline The Bahamas & $1,398.9$ & $1,488.7$ & $1,516.0$ & $1,598.1$ & $1,633.1$ & $1,617.6$ & $1,540.0$ \\
\hline Jamaica & $1,057.2$ & $1,105.4$ & $1,098.3$ & $1,147.0$ & $1,162.4$ & $1,192.2$ & $1,225,3$ \\
\hline Puerto Rico & $2,753,9$ & $2,923.2$ & $3,112.7$ & $3,053,9$ & $3,127.7$ & $3,378.5$ & $3,461.3$ \\
\hline Dominican Republic & $1,523.8$ & $1,636.4$ & $1,766.9$ & $1,775.9$ & $1,925.6$ & $2,211.4$ & $2,309.1$ \\
\hline \multicolumn{8}{|l|}{ Memorandum items: } \\
\hline Share of Dominica in Caribbean (percent) & 0.4 & 0.4 & 0.4 & 0.4 & 0.4 & 0.4 & 0.4 \\
\hline Share of Dominica in Eastern & & & & & & & \\
\hline Caribbean (percent) & 5.6 & 5.2 & 5.1 & 5.8 & 5.9 & 5.9 & 5.7 \\
\hline
\end{tabular}

Source: Caribbean Tourism Organization.

1/ Excludes Cancun and Cozumel. 


\section{Dominica: Cruiseship Passenger Arrivals in the Caribbean 1/}

(In thousands; unless otherwise indicated)

\begin{tabular}{|c|c|c|c|c|c|c|c|}
\hline & 1992 & 1993 & 1994 & 1995 & 1996 & 1997 & 1998 \\
\hline Caribbean & $8,790.3$ & $8,871.0$ & $8,850.3$ & $8,982.9$ & $9,939.0$ & $11,007.8$ & $11,146,0$ \\
\hline Eastern Caribbean & 931.4 & 927.7 & $1,010,3$ & $1,125.4$ & $1,221.8$ & $1,311.2$ & $1,503.6$ \\
\hline Antigua and Barbuda & 250.2 & 238.4 & 235.7 & 227.4 & 270.5 & 285.5 & 336.5 \\
\hline British Virgin Islands & 87.6 & 85.8 & 82.4 & 122.1 & 159.6 & 104.9 & 105.1 \\
\hline Dominica & 89.8 & 87.8 & 125.5 & 134.9 & 193.5 & 229.9 & 236.1 \\
\hline Grenada & 195.9 & 200.1 & 200.8 & 249.9 & 267.0 & 246.6 & 265.9 \\
\hline Montserrat & 5.6 & 8.8 & 11.0 & 9.0 & $\ldots$ & $\ldots$ & $\ldots$ \\
\hline St. Kitts and Nevis & 74.0 & 83.1 & 112.9 & 120.9 & 85.8 & 102.7 & 154.1 \\
\hline St. Lucia & 164.9 & 154.4 & 171.5 & 175.9 & 182.2 & 310.2 & 372.1 \\
\hline St. Vincent and the Grenadines & 63.4 & 69.3 & 70.5 & 85.3 & 63.2 & 31.4 & 33.8 \\
\hline $\begin{array}{l}\text { Other Caribbean } \\
\text { Of which: }\end{array}$ & $7,858.9$ & $7,943.3$ & $7,840.0$ & $7,857.5$ & $8,717.2$ & $9,696.6$ & $9,642.4$ \\
\hline The Bahamas & $2,139.4$ & $2,047.0$ & $1,805.6$ & $1,543.5$ & $1,687.1$ & $1,751.1$ & $1,729.9$ \\
\hline Jamaica & 649.5 & 629.6 & 595.0 & 605.2 & 658.2 & 711.7 & 673.7 \\
\hline Puerto Rico & $1,019.2$ & 968.1 & 976.9 & $1,001.1$ & $1,025.1$ & $1,227.4$ & $1,243.4$ \\
\hline Dominican Republic & 50.0 & 27.8 & 50.1 & 30.5 & 110.9 & 270.8 & 393.6 \\
\hline \multicolumn{8}{|l|}{ Memorandum items: } \\
\hline Share of Dominica in Caribbean (percent) & 1.0 & 1.0 & 1.4 & 1.5 & 1.9 & 2.1 & 2.1 \\
\hline \multicolumn{8}{|l|}{ Share of Dominica in Eastern } \\
\hline Caribbean (percent) & 9.6 & 9.5 & 12.4 & 12.0 & 15.8 & 17.5 & 15.7 \\
\hline
\end{tabular}

Source: Caribbean Tourism Organization.

1/ Excludes Cancun and Cozumel. 


\section{Dominica: Relations with the World Bank Group ${ }^{1}$ \\ (As of September 30, 1999)}

\section{Projects}

Dominica is a participant in the World Bank supported OECS Solid Waste Management Project which was approved in FY95 ${ }^{2}$ The objective of this operation is to reduce public health risks and protect the environmental integrity of the Eastern Caribbean islands and their coastal and marine systems, by improving solid waste management facilities. The total financing for this project is US\$6.1 million-US\$1.2 million from the World Bank Group, US $\$ 0.8$ million from the Global Environment Facility, US\$1.2 million from the Caribbean Development Bank, and US\$1.9 million from the EU. The government is contributing with US\$1 million from its own funds.

In FY95 the World Bank approved US\$6.07 million for a Basic Education Reform Project. The project is designed to improve the quality of basic education, expand access to secondary education, rehabilitate primary and secondary school facilities, and help curriculum development for primary and secondary schools.

In FY98 the World Bank approved US\$6 million for an OECS Telecommunications Reform Project. Dominica's share of this project is US\$1.2 million. The objective of the project is to introduce procompetition reforms in the telecommunications sector and increase the supply of informatics-related skills in the five OECS borrowing countries (Antigua and Barbuda does not participate in the project)

The OECS Emergency Recovery and Disaster Management Program, totaling US\$19.5 million, was approved by the World Bank in FY 99; Dominica's share in the project is US\$5.03 million. The project aims to support the physical and institutional efforts of the participating countries for disaster recovery and emergency preparedness and management. The project was declared effective on June 9, 1999.

\footnotetext{
${ }^{1}$ Source: World Bank.

${ }^{2}$ World Bank fiscal year begins on July 1 .
} 


\section{Financial Relations}

(In millions of U.S. dollars)

\section{Operations}

Basic Education Reform

OECS Solid Waste Management

OECS Telecommunications Reform

OECS Emergency Recovery

$\begin{array}{ccc}\text { Principal } & \text { Disbursed } & \text { Undisbursed } \\ 6.07 & 3.76 & 2.31 \\ 1.20 & 0.10 & 1.10 \\ 1.20 & 0.12 & 1.08 \\ 5.03 & 0.30 & 4.73\end{array}$

Gross disbursements and debt service during fiscal year

\begin{tabular}{lllllllll}
\multicolumn{9}{c}{ Actual } \\
$1993 \quad 1994$ & 1995 & 1996 & 1997 & 1998 & 1999 & & $\frac{\text { Projections }}{2000} 2001$
\end{tabular}

$\begin{array}{llllllllll}\text { Disbursements } & 0.2 & 0.1 & 0.2 & 0.1 & 0.5 & 1.9 & 1.4 & 1.5 & 1.9 \\ \text { Repayments } & 0.1 & 0.1 & 0.1 & 0.1 & 0.1 & 0.1 & 0.1 & 0.3 & 0.5 \\ \text { Interest and fees } & 0.1 & 0.1 & 0.1 & 0.1 & 0.1 & 0.1 & 0.1 & 0.2 & 0.2\end{array}$

\section{ECONOMIC AND SECTOR WORK}

The most recent Country Assistance Strategy dates from April 10, 1995. The World Bank is currently working on a new CAS which is expected to be presented to the Board in March 2000. The Medium-Term Economic Strategy Paper for the period 2000-02 will be prepared by the Government of Dominica in cooperation with the World Bank and the Caribbean Development Bank (CDB) and distributed at the June 2000 meeting of the Caribbean Group for Cooperation in Economic Development (CGCED). 


\section{Dominica: Financial Relations with the Caribbean Development Bank}

(As of Decernber 31, 1998)

(In millions of U.S. dollars) $1 /$

\begin{tabular}{lcccccc}
\hline & 1993 & 1994 & 1995 & 1996 & 1997 & 1998 \\
\hline Cumulative total credit approved & 71.75 & 68.23 & 71.76 & 86.15 & 98.67 & 98.85 \\
& & & & & & \\
Cumulative disbursements & 56.17 & 58.13 & 60.25 & 61.85 & 62.58 & 66.54 \\
& & & & & & \\
Disbursements 2/ & 1.44 & 1.97 & 2.11 & 1.15 & 2.61 & 3.76 \\
Ordinary capital resources & 0.36 & 0.84 & 0.43 & 0.44 & 0.43 & 1.69 \\
Special development fund & 1.08 & 1.13 & 1.49 & 0.71 & 2.18 & 2.07 \\
Other special fund resources & 0.00 & 0.00 & 0.19 & 0.00 & 0.00 & 0.00 \\
& & & & & & \\
Amortization 2/ & 1.87 & 2.19 & 2.12 & 2.06 & 2.43 & 2.66 \\
Ordinary capital resources & 0.04 & 0.05 & 0.07 & 0.09 & 0.20 & 0.34 \\
Special development fund & 1.30 & 1.60 & 1.52 & 1.48 & 1.73 & 1.89 \\
Other special fund resources & 0.53 & 0.54 & 0.53 & 0.49 & 0.50 & 0.43 \\
& & & & & & \\
Outstanding debt (end of period) & 36.38 & 37.32 & 41.69 & 41.20 & 40.82 & 42.09 \\
& & & & & & \\
Intercst and commitment fees 2/ & 1.38 & 1.34 & 1.33 & 1.11 & 1.24 & 1.24 \\
Ordinary capital resources & 0.29 & 0.29 & 0.33 & 0.27 & 0.34 & 0.38 \\
Special development fund & 0.85 & 0.85 & 0.77 & 0.66 & 0.73 & 0.71 \\
Other special fund resources & 0.24 & 0.20 & 0.23 & 0.18 & 0.17 & 0.15 \\
\hline
\end{tabular}

Source: Caribbean Development Bank.

1/ Including valuation adjustments.

2/ Ordinary capital resources are hard loans, and spccial developments funds and other special fund resources are soft loans. 
This page intentionally left blank

CInternational Monetary Fund. Not for Redistribution 


\section{INTERNATIONAL MONETARY FUND}

EXTERNAL

\section{Public Information Notice}

Public Information Notice (PIN) No. 00/8

FOR IMMEDIATE RELEASE

February 16,2000
International Monetary Fund

$70019^{\text {th }}$ Street, NW

Washington, D. C. 20431 USA

\section{IMF Concludes Article IV Consultation wlth DomInica}

On January 10, 2000, the Executive Board concluded the Article IV consultation with Dominica. ${ }^{1}$

\section{Background}

Economic growth averaged about $2 \frac{1}{2}$ percent a year in the 1990 s, and the structure of the economy continued to move away from agriculture as the key banana sector contracted further. As in other countries in the region, the factors behind the contraction of the banana sector have included plant disease, export price declines, and strong export dependence on uncertain preferential access to the European Union (EU) market. Unemployment remains high.

Economic activity strengthened in 1998, and inflation remained low. Despite a decline in agriculture and construction, real GDP grew by $31 / 2$ percent, largely as a result of a recovery in manufacturing production along with the continued expansion of services. The 12-month increase in consumer prices was 0.6 percent in September 1999.

The nonfinancial public sector deficit was broadly unchanged at 21/2 percent of GDP in $1998 / 99$ (fiscal year starts July 1), but public saving declined. The central government deficit fell in

\footnotetext{
${ }^{1}$ Under Article IV of the IMF's Articles of Agreement, the IMF holds bilateral discussions with members, usually every year. A staff team visits the country, collects economic and financial. information, and discusses with officials the country's economic developments and policies. On return to headquarters, the staff prepares a report, which forms the basis for discussion by the Executive Board. At the conclusion of the discussion, the Managing Director, as Chairman of the Board, summarizes the views of Executive Directors, and this summary is transmitted to the country's authorities. In this PIN, the main features of the Board's discussion are described.
} 
relation to GDP due partly to higher grant receipts, while government saving was virtually unchanged.

The gross debt of the nonfinancial public sector rose slightly, to 59 percent of GDP at end-June 1999, but the gross external debt fell somewhat to 33 percent of GDP. The stock of external arrears was virtually eliminated, and external debt-service obligations declined to 5 percent of exports of goods and nonfactor services, the lowest level in recent years.

The external current account deficit narrowed to 7 percent of GDP in 1998. Although banana exports and net travel receipts fell, there was a strong recovery in exports of manufactures. Visitor arrivals grew by 4 percent in 1998, but the share of arrivals staying in hotels declined. Net current and capital transfers from emigrants, workers abroad and foreign donors remained substantial, helping to cover the large trade deficit, with capital transfers to the government amounting to almost half the total. Net capital inflows have been sufficient in recent years to cover the current account deficits and permit surpluses in the overall balance of payments.

Broad money has continued to grow at a slightly higher rate than nominal GDP. At the same time, commercial banks expanded credit to the private sector at a fast pace during 1998 and 1999, while maintaining a net external creditor position. Interest rates have declined somewhat since end-1997, with lending rates at around 11/2 percent per annum and deposit rates 4 percent per annum in 1998/99.

Dominica is a member of the Eastern Caribbean Currency Union, which maintains the Eastern Caribbean dollar as a common currency. The Eastern Caribbean dollar has been pegged to the U.S. dollar since 1976.

In the structural area, the maximum external tariff rate was reduced from 30 percent to 25 percent in January 1999, in line with Phase I!I of the scheduled reductions in the CARICOM common external tariff.

Looking ahead, the government is planning large-scale investments for the period through 2003 , including the building of an international airport and supporting infrastructure, as well as a stadium, as part of a strategy to promote tourism development. Execution of this investment program is expected to result in a sharp widening of the public sector deficit, an increase in the external current account deficit, and substantially higher debt-service obligations in the next few years.

\section{Executive Board Assessment}

Directors noted that, despite the contraction in agriculture and construction, the shift in the structure of the economy away from banana production to a higher level of activity in the services and small manufacturing sectors had helped strengthen the economic recovery. However, Directors observed that moderate growth of real GDP in recent years has been insufficient to bring about a reduction in unemployment, and expressed support for the authorities' medium-term objective of achieving sustained growth of output and employment through further economic diversification and financial stability. Directors noted that achieving 
these objectives would require raising public saving to help fund needed investments and promoting private sector activity through structural reforms.

To support the saving effort, Directors underscored the need for expenditure restraint, particularly of the wage bill. They welcomed the authorities' plan to broaden the tax base by replacing a number of indirect taxes with a value-added tax, and by streamlining tax exemptions.

Directors noted that the authorities have an ambitious public investment program, including the construction of a new airport and stadium, that would entail a near doubling of Dominica's public external debt in the near term. They observed that a large portion of the borrowing is being contracted on commercial terms and that this would contribute to a sharp increase in debt service obligations, greatly complicating fiscal management. Directors urged the authorities to scale down the public investment program to a more manageable level, and welcomed their intention to conduct a comprehensive review of the public investment program and the financing plan for the airport with the assistance of the World Bank. Directors encouraged the authorities to minimize borrowing on commercial terms by securing greater participation of multilateral lending instifutions, the private sector, and donors.

Directors stressed the need for accelerating structural reforms, so as to increase economic efficiency, support growth, and buttress the public finances. They called for action in the areas of price decontrol, trade liberalization, civil service reform, and privatization. In particular, a timetable for privatizing the National Commercial Bank should be established, with proceeds allocated to help finance the authorities' investment program. At the same time, Directors encouraged the authorities to maintain close surveil ance over the financial system, and particularly urged strengthening of the supervision of nonbank and offshore financial institutions and measures to prevent money laundering.

Directors urged the authorities to improve the coverage and quality of economic statistics, which do not currently provide an adequate basis for policy formulation or Fund surveillance. In particular, efforts should be made to improve data on national accounts, government finances, and labor markets.

Public Information Notices (PINs) are issued, (i) at the request of a member country, following the conclusion of the Articte IV consultation for countries seeking to make known the views of the IMF to the public. This action is intended to strengthen IMF surveillance over the economic policies cf member countries by increasing the transparency of the IMF's assessment of these policies; and (ii) following policy discussions in the Executive Board at the decision of the Board. As part of a pilot project, the staff report (use the free Adobe Acrobat Reader to view this pdf file) for the 1999 Article IV consultation with Dominica is also available on the IMF's website (http://wmw.imf.org). 
Dominica: Selected Economic Indicators

\begin{tabular}{|c|c|c|c|c|c|}
\hline & 1995 & 1996 & 1997 & 1998 & $\begin{array}{r}\text { Proj. } \\
1999 \\
1\end{array}$ \\
\hline & \multicolumn{5}{|c|}{ Annual percentage changes } \\
\hline \multicolumn{6}{|l|}{ Output and prices } \\
\hline Real GDP & 1.6 & 3.1 & 2.0 & 3.5 & 3.5 \\
\hline \multirow[t]{2}{*}{ Consumer prices (average) } & 1.4 & 2.0 & 2.2 & 1.5 & 1.6 \\
\hline & \multicolumn{5}{|c|}{ in percent of $\mathrm{GDP}$} \\
\hline \multicolumn{6}{|l|}{ Savings and Investment } \\
\hline Gross national saving & 15.3 & 16.9 & 20.7 & 23.0 & 22.1 \\
\hline \multirow[t]{2}{*}{ Gross domestic investment } & 32.4 & 29.7 & 30.0 & 30.0 & 34.1 \\
\hline & \multicolumn{5}{|c|}{ In millions of U.S. dollars unless otherwise } \\
\hline \multicolumn{6}{|l|}{ External sector } \\
\hline Merchandise exports (f.o.b.) & 50.3 & 52.5 & 53.5 & 62.3 & 65.8 \\
\hline Merchandise imports (f.o.b.) & 103.2 & 100.2 & 104.0 & 107.3 & 121.9 \\
\hline Gross tourism receipts & 41.5 & 46.3 & 50.3 & 46.8 & 47.7 \\
\hline Current account balance & -38.1 & -30.1 & -22.6 & -18.2 & -32.9 \\
\hline Current account (as percent of GDP) & -17.0 & -12.8 & -9.3 & -7.0 & -12.0 \\
\hline Overall balance & 7.0 & 0.8 & 0.7 & 3.8 & 2.2 \\
\hline External publis debt stock (end of & 103.0 & 102.5 & 88.9 & 90.0 & 123.0 \\
\hline \multirow[t]{2}{*}{ Real effective exchange rate (end of } & -3.2 & 0.9 & 6.6 & -2.7 & $\ldots$ \\
\hline & \multicolumn{5}{|c|}{ Changes in percent of broad money at } \\
\hline Monetary sector & & & & & \\
\hline Net domestic assets & 10.7 & -5.9 & 5.5 & -0.1 & 8.1 \\
\hline Credit to private sector & 11.0 & 3.8 & 6.1 & 7.6 & 7.5 \\
\hline \multirow[t]{3}{*}{ Broad money (M2) } & 23.1 & 2.0 & 3.5 & 6.9 & 8.1 \\
\hline & \multicolumn{5}{|c|}{ In percent of GDP } \\
\hline & $1995 /$ & $1996 / 9$ & $1997 / 9$ & $1998 / 9$ & $1999 / 0$ \\
\hline \multicolumn{6}{|l|}{ Public sector $3 /$} \\
\hline Revenue and grants & 41.0 & 44.3 & 37.3 & 37.6 & 38.7 \\
\hline Expenditure & 38.7 & 43.8 & 40.0 & 40.1 & 47.7 \\
\hline Saving & 4.1 & 2.1 & 4.0 & 3.0 & 2.3 \\
\hline Overall balance & 2.3 & 0.5 & -2.7 & -2.5 & -9.0 \\
\hline
\end{tabular}

Sources: Dominican authorities; Eastern Caribbean Central Bank; and IMF staff

1/ Based on authorities' plans.

2/ Percentage change.

$3 /$ Fiscal year begins July 1 . 


\section{Statement by Thomas A. Bernes, Executive Director for Dominica \\ January 10, 2000}

1. My Dominican authorities are grateful for the work of the IMF team during the last Article IV Consultation, and particularly thank Mr. Rosales for all of his guidance and advice during his period of leading missions to Dominica. We wish him well in his new assignment.

2. Fund staff play a useful role in the economic dialogue of small countries like Dominica and the annual consultations which Dominica has enjoyed over the years serve a very important function. Despite the fact that $I$ have made this point in the past, it is still useful to remind colleagues that because of its small size, Dominica finds it difficult to amass ail of the skills necessary to carry out on a regular basis, the kind of analytical exercise of economic developments that is ably undertaken by the Fund and others. Against this background of weak institutional capacity, the Fund offers an invaluable technical assistance role during the annual consultation. For the coming year, we look forward to the regional approach to be taken by staff as we consider the Caribbean region a prime candidate for regional surveillance.

3. The 1999 Article IV Consultation has provided the authorities an opportunity to reflect on their current economic path and has helped the government to assess its current growth strategy and medium-term outlook. My authorities are especially thankful for the staff's assessment on the feasibility of a new airport and recommendations regarding regulation of credit unions, as outlined in Boxes $I$ and 3 . For the most part, the Dominican government shares the concerns expressed in the staff appraisal and, in particular, agree that achievement of sustained output growth and employment requires raising public savings and making progress in structural reforms. However, my authorities have established a set of priorities that they consider critical to the long-term development of Dominica and intend to pursue them at a pace somewhat faster than the staff's desired path.

\section{Policy Issues}

4. Let me focus on the key issues raised in the paper without repeating the background on recent developments as they are well-articulated in the staff report. The main issues surround the public sector investment program (PSIP) which includes plans to build a new international airport, stadium, improve roads and water infrastructure. Staff's view is that "serious questions arise about the scale, funding, and phasing of this program" (paragraph 38) and, as a consequence, Domunica should rethink its PSIP. In particular, staff raise, rightfully, the impact of these projects on Dominica's external debt position and on the sustainability of a sound fiscal position. Staff recommend that the government consider the 
early adoption of fiscal measures to bolster the public finances, including the introduction of a value added tax (VAT).

5. Directors should note that, currently, Dominica remains among the most vulnerable English speaking countries in the Caribbean. Its economy has been dominated almost entirely by agriculture, mainly bananas, and as staff have described, this sector is undergoing a major contraction. My authorities, in planning for future generations, have embarked on a plan to diversify the economy, and in particular given its location, geography, and climate, have chosen to pursue tourism. Dominica offers a special attraction in that the island abounds in natural beauty, complete with pristine forests, lakes and waterfalls which appeal to the ecotourist-niche market. However, a major constraint to the development of tourism has been the inadequacy of airlift capacity given the constraints of a tiny domestic airport and the absence of night landing. It is against this background that Directors need to view the authorities PSIP, and specifically the airport. A new airport symbolizes Dominica's need to take-off in another economic direction. While the scale of this project is large, it represents hope for new opportunities.

\section{Looking to the Future}

6. Staff have emphasized the need for the government to scale back the airport, to reexamine the assumptions underlying the consultants' feasibility study and to reassess the financing requirements. Since the mission was completed, rny authorities have been engaging in discussions with several companies to review possibilities of build-operate-transfer (BOT) arrangements and are prepared to consider any option to minimize any adverse financial implications of such a large undertaking. Furthermore, the World Bank will be sending a mission later this month (January 17-21, 2000) to review the feasibility study and advise the government on all aspects of the project, including the possibility of including multilateral concessional financing. The govermment will reserve finalization of any concrete plans until after this evaluation has been completed. It is important that Directors appreciate that the government is prepared to review their plans for the airport in order to arrive at the best possible set of financing arrangements. However, it should remain clear that the government is committed to the new airport and intends to go ahead with this project in the long-term interests of the country.

7. On the introduction of a VAT, my authorities are committed to its implementation but are moving ahead in phases, along the lines recommended by $\mathrm{FAD}$. The current process involves a series of educational seminars with both public and private participation in orcer to ensure full consultation as well as understanding of the new tax. While staff call for an early adoption of its introduction, it is important that the process be participatory and with the support and comprehension of the broad society. The authorities wish to avoid any missteps in the introduction and implementation of the VAT.

8. Staff's concerns about the supervision of the financial system are well taken and efforts are already underway to bring credit unions under more strict guidelines in accordance with regional initiatives on cooperatives. Dominica aims, with the able expertise 
of the Eastern Caribbean Central Bank (ECCB), to maintain the highest international standards in its financial system. In December 1999, Dominica introduced an amendment to the Offshore Banking Act making the ECCB more explicitly involved in the surveillance of the offshore financial sector by providing the Central Bank with the necessary legal authority to assist the Minister of Finance in its regulation and supervision.

9. I am pleased to report that there were no major Y2K-related problems encountered during the turn of the new year to 2000 in Dominica, and banks have reported a smooth transition.

10. Finally, Dominica intends to participate in the IMF's pilot study on transparency with the publication of its staff report and looks forward to continued good dialogue with the Fund throughout 2000 . 